\title{
Gold-and silver-bearing assemblages in the Ann-Mason copper porphyry deposit, Yerington, Nevada
}

\author{
Hannah M. Aird ", Ceara K. Purcell, Nancy DeWitt, James Matthews, Twyla Capurro, \\ Justin Claiborne, Jocelyn Bermudez, Zachary Meisel \\ Department of Geological and Environmental Sciences, California State University, Chico, Chico, CA 95929, USA
}

\section{A R T I C L E I N F O}

\section{Keywords:}

Ann-Mason

Porphyry

Gold

Silver

Sulfides

Mineralisation

\begin{abstract}
A B S T R A C T
Porphyry deposits are an important source of copper and their value may be upgraded by minor contents of precious metals, if they are extractable. The mechanisms for enrichment of precious and base metals in these systems are not well understood. This study investigates the deportment of trace metals in the Ann-Mason porphyry deposit, including gold, silver, palladium, mercury, lead and bismuth. Petrographic and geochemical data are integrated to characterise the size and habit of minerals, the host mineral assemblages, and their association with alteration assemblages. Ann-Mason is one of several ore deposits hosted by the Yerington batholith in Nevada, and is being assessed for copper extraction from bornite and chalcopyrite ore assemblages, associated with potassic alteration. Mineralisation assemblages at Ann-Mason have been categorised as chalcopyritebornite, chalcopyrite-pyrite and pyrite > chalcopyrite zones. Limited two-metre assay data indicates that gold is most closely associated with bornite, although it is found in all three mineralisation zones. Analysis by SEMEDS shows that trace elements are mostly present as microparticles hosted by sulfide minerals. Of the 438 grains measured, $89 \%$ are hosted by a sulfide mineral, with $68 \%$ hosted by bornite. Silver is most commonly present as hessite and gold as electrum, hosted by bornite and associated with potassic alteration. Palladium, mercury and bismuth are most commonly observed as telluride and selenide minerals. Palladium minerals are associated with potassic alteration, while mercury and bismuth minerals are mostly found with sericitic alteration. High fineness native gold is observed as three round blebs hosted by pyrite or silicates. Observations suggest that the trace metals in the chalcopyrite-bornite zone may have been incorporated by bornite and chalcopyrite, and exsolved upon cooling. In the chalcopyrite-pyrite and pyrite > chalcopyrite zones, the trace metals may have been deposited directly from a mineralising hydrothermal fluid and incorporated into the growing sulphide minerals. These findings have implications for the paragenesis of porphyry deposits, as well as for the milling processes that would be needed to extract precious metals at the Ann-Mason porphyry deposit.
\end{abstract}

\section{Introduction}

Porphyry copper deposits (PCDs) produce around $60 \%$ of the world's copper (Johnson et al., 2014) and provide a significant portion of the global supply of gold and tellurium (Goldfarb, 2014), yet the mechanisms of this metal enrichment are still not fully understood. The presence of minor amounts of precious metals such as gold and silver and critical metals such as tellurium, bismuth and the platinum group elements may upgrade the value of the deposit if they are present in a form that is economic to extract (Schulz et al., 2018). Characterisation of the trace mineral assemblages that host precious metals, known as geometallurgy, allows a more precise determination of the economic resource; informs industry decisions on the most efficient extraction and processing techniques; and allows for a more complete interpretation of the processes involved in deposition of these mineral assemblages by the mineralising fluids.

The Ann-Mason deposit is a porphyry copper deposit located near Yerington, Nevada (now called the Mason deposit by Hudbay Minerals). It has a completed preliminary economic assessment and has a combined indicated and measured resource of $2,219 \mathrm{Mt}$ at $29 \mathrm{wt} \% \mathrm{Cu}$, with a 0.2 wt $\%$ Cu cut-off grade (Hudbay Minerals website, May 2021). Design of the planned mining and processing operations is underway, making this the ideal time for a geometallurgical study of the precious metal deportment in the $\mathrm{Cu}-$ rich ore zones of the deposit. Geometallurgy is an

\footnotetext{
* Corresponding author.

E-mail address: haird@csuchico.edu (H.M. Aird).
} 
interdisciplinary approach to characterising the metal resources within a deposit. It combines rock type and characteristics with mineralogy and metal deportment to define different domains of a deposit, which may require different extraction and processing methods to one another. The findings of a geometallurgical study can be used to inform design of the engineering and mineral processing operations for a mine, as well as refine geologic models for ore genesis (Gregory et al., 2013).

Metal deportment describes the distribution, mineral species, textural relationships, grain size and host mineralogy of a given metal within a deposit. Optimisation of extraction and processing techniques for a particular deposit depends heavily on the deportment of metals of interest within different domains of the deposit (Agorhom et al., 2013). Precious metals in porphyry deposits may be present as discrete minerals (precious metal sulphides, tellurides, selenides, alloys, etc) or incorporated into the structures of copper sulphides as 'invisible' gold or silver (Arif and Baker, 2004; Harris, 1990), even in much higher-grade ores than those seen at the Ann-Mason deposit (Reich et al., 2013). They range in size from $<1 \mu \mathrm{m}$ to $>100 \mu \mathrm{m}$, and may be hosted within or at grain boundaries between other minerals, including silicates or sulphides (Agorhom et al., 2013; Arif and Baker, 2004). The size of grains and their location within an assemblage determine the degree of milling required to efficiently extract the metals (Tungpalan et al., 2015), and the speciation and host mineralogy determine the most efficient ore processing techniques in order to optimise metal recovery. The predicted recovery and market value of a precious metal is combined with its distribution and concentrations within the deposit to determine whether it is economic to undertake the extra processing required for extraction of the precious metals in addition to copper.

Assay data from the Ann-Mason deposit shows elevated gold and silver concentrations generally associated with the bornite-rich region of the deposit, but the metal deportment has never been determined. This study uses petrography, SEM EDS analyses and ICP-MS WDS data to characterise the deportment of silver, gold and palladium bearing microparticles throughout the ore zones of the Ann-Mason deposit, to determine the processes of formation and inform industry mineral processing decisions.

\section{Geology of the Ann-Mason deposit}

The Ann-Mason deposit is one of several porphyry and skarn deposits hosted at the edge of the Middle Jurassic Yerington Batholith (169-168 Ma; Dilles and Wright, 1988). Magmatism in the region was caused by the Middle Jurassic magmatic arc (170-165 Ma) which erupted the subaerial Artesia Lake Volcanics, and emplaced the cogenetic Yerington Batholith; a shallow $(\sim 1 \mathrm{~km})$ composite intrusion comprising three successive plutons (Dilles, 1987). The McLeod Hill quartz monzodiorite (Jqmd, 170.0 \pm 1.4 Ma; Banik et al., 2017; Carten, 1986; Proffett, 2007) was intruded by the Bear quartz monzonite (Jbqm, $169.6 \pm 1.3 \mathrm{Ma}$, Banik et al., 2017) which was later intruded by the Luhr Hill granite (Jgp, $169.4 \pm 1.5 \mathrm{Ma}$, Banik et al., 2017). The later stages of the Luhr Hill granite intrusion produced granite porphyry (Jgp) dykes (168.5 Ma; Dilles and Wright, 1988), which are spatially and temporally associated with quartz veins and copper mineralisation. The Middle Jurassic rocks are unconformably overlain by Oligocene silicic ignimbrites and Miocene andesitic lava flows (Fig. 1). The entire sequence of Mesozoic rocks were tilted $90^{\circ}$ through Basin and Range faulting, and therefore expose a near-total Jurassic cross section at the surface (Dilles and Einaudi, 1992). This makes the region ideal for studying the conditions of formation of the porphyry and skarn deposits distributed around the edge of the batholith.

\subsection{Alteration and mineralisation at Ann-Mason}

The Ann-Mason Deposit is located on the southern margin of the Yerington Batholith, and comprises zones of altered intrusive rocks at about 2.5-4 km paleodepth (Dilles and Einaudi, 1992). Alteration of the primary mineralogy was caused by the interaction of a high-temperature fluid with the host plutonic rocks, and is commonly associated with the deposition of ore minerals. The majority of ore mineralisation is centered around the Luhr Hill porphyritic granite (Jpg) and cogenetic granite dyke swarm (Jgp), which are believed to be the source of the mineralising hydrothermal fluid. Individual units of the dyke swarm have been dated to $169.0 \pm 1.2 \mathrm{Ma}$ (Jgp1), $168.7 \pm 1.1 \mathrm{Ma}$ (Jgp1.5), and $168.7 \pm 1.2 \mathrm{Ma}(\mathrm{Jgp} 2)$. The oldest dyke, Jgp1, is the most mineralised (Proffett, 1977, 2009; Carten, 1986; Dilles et al., 2000).

Main stage alteration comprised propylitic (albite + epidote +

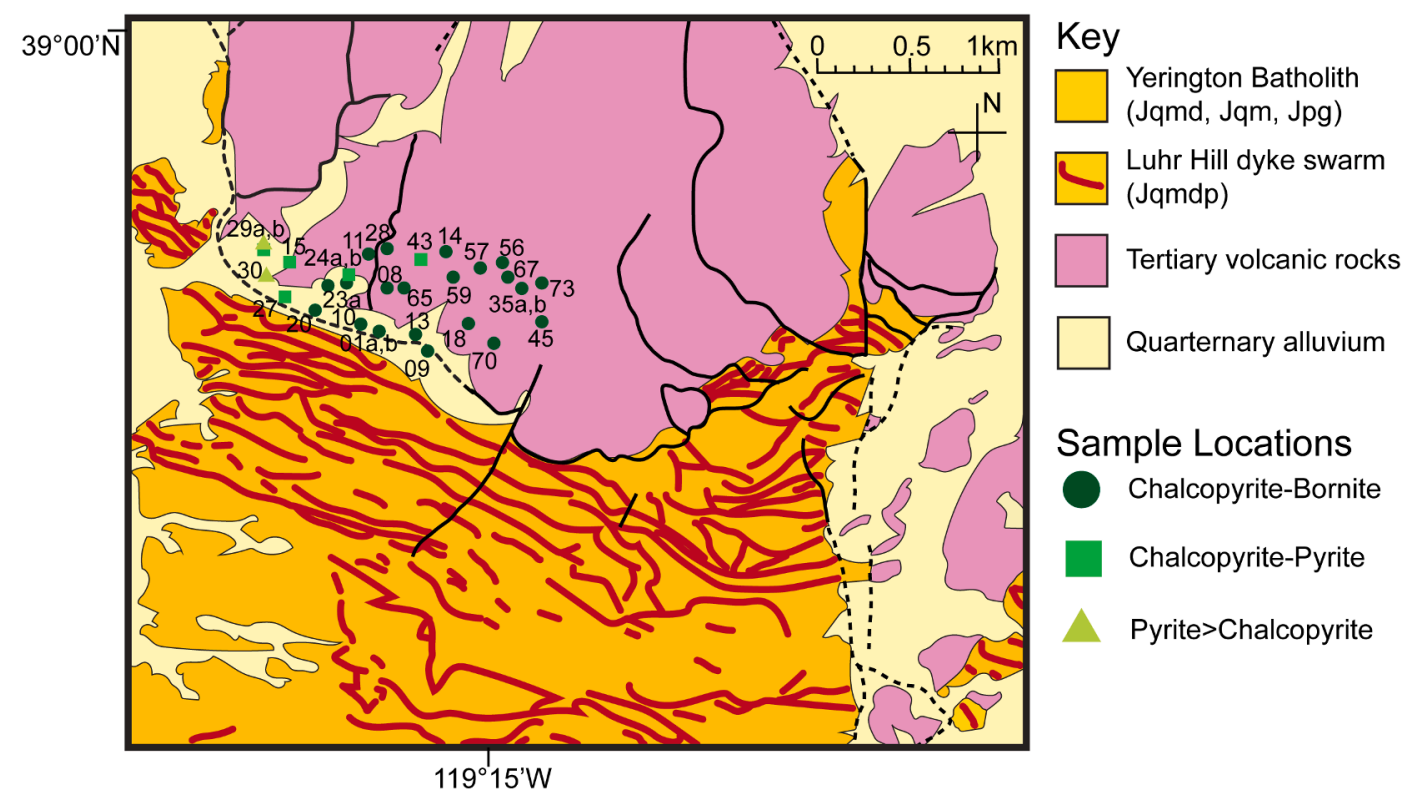

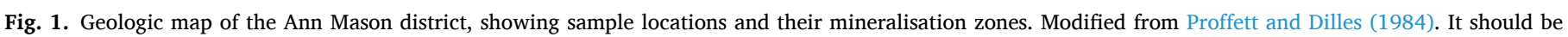

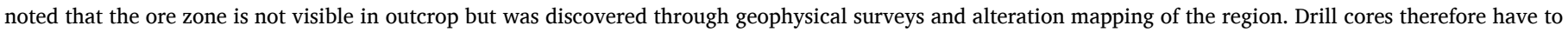
pass through the Tertiary volcanics and cross the gently dipping Singatse fault and to reach the ore zone. 
actinolite + chlorite) above $4 \mathrm{~km}$ paleodepth, sodic-calcic (oligoclaseactinolite-sphene) from 3.5 to $>6 \mathrm{~km}$, and potassic (biotite $+\mathrm{K}$ feldspar) from 1 to $6 \mathrm{~km}$ (Dilles et al., 1992; Dilles and Einaudi, 1992). Late stage sodic, chloritic and sericitic alteration formed a funnel-shaped zone from $4 \mathrm{~km}$ paleodepth upwards, and comprised early sodic (albitechlorite-vermiculite to albite-sericite-pyrite) alteration, which is cut by pyrite- and tourmaline-rich veins with sericitic alteration selvages that grade laterally into sericite-chlorite alteration (Dilles and Einaudi, 1992).

Copper mineralisation is predominantly spatially associated with zones of potassic alteration, with granite porphyry dykes, with quartz veins and saline fluid inclusions (Dilles and Einaudi, 1992). The most important $\mathrm{Cu}$ ore minerals are bornite and chalcopyrite, and the mineralised region may be divided into several zones of mineralisation: chalcopyrite-bornite (Ccp-Bn), chalcopyrite only (Ccp), chalcopyritepyrite (Ccp-Py), pyrite $>$ chalcopyrite (Py $>\mathrm{Ccp}$ ) and pyrite only (Py). The Ccp-Bn zone is exposed at the greatest paleodepth, grading upwards and outwards through Ccp, Ccp-Py and Py > Ccp to Py at shallower depths and greater paleolateral extents.

Our samples contain potassic alteration overprinted by late stage albite-chlorite and sericite-quartz alteration, and are from the Ccp-Bn, Ccp-Py and Py > Ccp mineralisation zones (Fig. 1).

\section{Methods}

Thirty samples were collected from the Entrée Gold (now Hudbay Minerals) drillcore repository in Yerington, Nevada, which contains the core from all Anaconda and Entrée Gold drilling operations at AnnMason. Hudbay Minerals determined, through the geochemistry and core logging of core from 79 drill holes, that $\mathrm{Au}$ and $\mathrm{Ag}$ are associated with bornite-enriched zones, which is consistent with the literature (e.g. Arif and Baker, 2004) and with unpublished EPMA sulphide analyses by John Dilles (pers. comm.). Samples for this study were therefore selected based on two metre assay data from Hudbay Minerals: two metre sections with the most elevated $\mathrm{Au}$ and $\mathrm{Ag}$ concentrations were targeted and $10-20 \mathrm{~cm}$-long core samples were chosen based on visual inspection of the two metre section. Where possible samples containing visible sulphides were preferentially selected, on the basis of the observed correlation between Au concentrations and bornite content by Hudbay Minerals (Table 1). A range of samples was also chosen to represent and investigate a variety of host rocks, several alteration assemblages and the three mineralisation assemblages (Table 2).

Polished sections were produced and petrographically described using an Olympus BX51 microscope to determine the primary and secondary textures and mineral assemblages. Photomicrographs were taken of notable features of each sample using a Stream Essentials SC30 Camera, documenting key minerals and textures in plane polarised and cross polarised transmitted light and in reflected light. Reflected light microscopy was used to determine the sulphides and other opaques in each sample.

Energy-dispersive spectroscopy (EDS) scans were performed on sulphides and gold- and silver-bearing minerals within the samples using a Tescan Vega 3 SEM to semi-quantitatively determine the chemical composition of the minerals and allow more precise identification. This technique detects the presence of elements, and gives an approximation of their relative abundance, but cannot be used to definitively determine composition. Back-scattered electron (BSE) imaging with a beam current of 7-14nA was commonly used to find the minerals of interest, which display as bright white in BSE due to their higher atomic numbers relative to the surrounding silicate minerals. An acceleration voltage of $10-30 \mathrm{kV}$ was used to reach between 10,000 and 25,000 counts per second at a working distance of $10 \mu \mathrm{m}$ to establish proper conditions for the EDAX x-ray software to determine chemical assemblages. Spot size was between 90 and $150 \mathrm{~nm}$.

Due to the semi-quantitative nature of the SEM-EDS analyses, representative examples of a few Ag-bearing minerals (electrum and

Table 1

Samples collected for this study with 2 m assay data for copper, gold and silver supplied by Entrée Gold (now Hudbay Minerals).

\begin{tabular}{|c|c|c|c|c|c|c|c|}
\hline Drillhole & Mineralization & $\mathrm{Cu}(w \mathrm{t} \%)$ & Au (ppm) & Ag (ppm) & $\mathrm{Ag} / \mathrm{Au}$ & $\mathrm{Ag} / \mathrm{Cu}$ & $\mathrm{Au} / \mathrm{Cu}$ \\
\hline EG-AM-01a & Ccp-Bn & 1.18 & 0.17 & 4.38 & 25 & 0.00037 & 0.00001 \\
\hline EG-AM-01b & Ccp-Bn & 0.44 & 0.23 & 2.24 & 10 & 0.00051 & 0.00005 \\
\hline EG-AM-08 & Ccp-Bn & 1.35 & 0.36 & 7.14 & 20 & 0.00053 & 0.00003 \\
\hline EG-AM-09 & Ccp-Bn & 0.52 & 0.14 & 2.98 & 22 & 0.00058 & 0.00003 \\
\hline EG-AM-10 & Ccp-Bn & 0.72 & 0.14 & 2.97 & 22 & 0.00041 & 0.00002 \\
\hline EG-AM-11 & Ccp-Bn & 0.61 & 0.18 & 4.10 & 23 & 0.00067 & 0.00003 \\
\hline EG-AM-13 & Ccp-Bn & 0.61 & 0.18 & 3.90 & 21 & 0.00064 & 0.00003 \\
\hline EG-AM-14 & Ccp-Bn & 0.54 & 0.19 & 5.30 & 29 & 0.00098 & 0.00003 \\
\hline EG-AM-18 & Ccp-Bn & 0.42 & 0.31 & 0.90 & 3 & 0.00021 & 0.00007 \\
\hline EG-AM-20 & Ccp-Bn & 1.66 & 0.08 & 0.90 & 11 & 0.00005 & 0.00000 \\
\hline EG-AM-23a & Ccp-Bn & 0.65 & 0.13 & 1.50 & 11 & 0.00023 & 0.00002 \\
\hline EG-AM-24b & Ccp-Bn & 1.02 & 0.18 & 3.10 & 18 & 0.00030 & 0.00002 \\
\hline EG-AM-28 & Ccp-Bn & 1.11 & 0.22 & 5.10 & 24 & 0.00046 & 0.00002 \\
\hline EG-AM-35a & Ccp-Bn & 1.00 & 0.31 & 8.20 & 26 & 0.00082 & 0.00003 \\
\hline EG-AM-35b & Ccp-Bn & 0.29 & 0.10 & 1.90 & 20 & 0.00066 & 0.00003 \\
\hline EG-AM-45 & Ccp-Bn & 0.63 & 0.36 & 2.10 & 6 & 0.00033 & 0.00006 \\
\hline EG-AM-56 & Ccp-Bn & 0.81 & 0.19 & 5.00 & 27 & 0.00062 & 0.00002 \\
\hline EG-AM-57 & Ccp-Bn & 1.21 & 0.46 & 6.60 & 14 & 0.00055 & 0.00004 \\
\hline EG-AM-59 & Ccp-Bn & 0.95 & 0.27 & 5.60 & 21 & 0.00059 & 0.00003 \\
\hline EG-AM-65 & Ccp-Bn & 0.73 & 0.24 & 3.40 & 14 & 0.00047 & 0.00003 \\
\hline EG-AM-67 & Ccp-Bn & 0.68 & 0.32 & 4.50 & 14 & 0.00066 & 0.00005 \\
\hline EG-AM-70 & Ccp-Bn & 0.57 & 0.13 & 3.60 & 27 & 0.00063 & 0.00002 \\
\hline EG-AM-73 & Ccp-Bn & 1.00 & 0.32 & 8.00 & 25 & 0.00080 & 0.00003 \\
\hline EG-AM-15 & Сcp-Py & 1.16 & 0.08 & 1.90 & 23 & 0.00016 & 0.00001 \\
\hline EG-AM-24a & Сcp-Рy & 0.63 & 0.09 & 1.60 & 18 & 0.00025 & 0.00001 \\
\hline EG-AM-27 & Ccp-Py & 0.58 & 0.04 & 0.60 & 14 & 0.00010 & 0.00001 \\
\hline EG-AM-29b & Сcp-Рy & 0.70 & 0.14 & 0.70 & 5 & 0.00010 & 0.00002 \\
\hline EG-AM-43 & Сcp-Рy & 1.04 & 0.95 & 1.80 & 2 & 0.00017 & 0.00009 \\
\hline EG-AM-29a & $\mathrm{Py}>\mathrm{Ccp}$ & 0.40 & 0.06 & 0.60 & 10 & 0.00015 & 0.00002 \\
\hline EG-AM-30 & Py $>$ Ccp & 0.31 & 0.50 & 0.50 & 1 & 0.00016 & 0.00016 \\
\hline Mean Ccp-Bn & & 0.81 & 0.23 & 4.06 & 19 & 0.00053 & 0.00003 \\
\hline Mean Ccp-Py & & 0.82 & 0.26 & 1.32 & 13 & 0.00016 & 0.00003 \\
\hline Mean Py > Ccp & & 0.36 & 0.28 & 0.55 & 5 & 0.00016 & 0.00009 \\
\hline
\end{tabular}


Table 2

Samp`les collected for this study, categorized by mineralization zone, alteration type and original lithology. Samples in italics show moderate sericite-quartz alteration, and samples in bold italics show intense sericite-quartz alteration.

\begin{tabular}{|c|c|c|c|c|}
\hline \multirow{2}{*}{$\begin{array}{l}\text { Mineralization } \\
\text { Zones }\end{array}$} & \multirow{2}{*}{$\begin{array}{l}\text { Alteration } \\
\text { Zones }\end{array}$} & \multicolumn{3}{|l|}{ Lithology } \\
\hline & & $\begin{array}{l}\text { Granodiorite } \\
\text { (Jqmd) }\end{array}$ & $\begin{array}{l}\text { Quartz } \\
\text { Monzonite } \\
\text { (Jbqm) }\end{array}$ & $\begin{array}{l}\text { Quartz } \\
\text { Monzonite } \\
\text { Porphyry Dikes } \\
\text { (Jgp) }\end{array}$ \\
\hline \multirow[t]{11}{*}{ Cpy-Bn } & \multirow[t]{11}{*}{ Potassic } & \multirow[t]{11}{*}{ EG-AM-20 } & EG-AM-01a & EG-AM-01b \\
\hline & & & EG-AM-08 & EG-AM-10 \\
\hline & & & EG-AM-09 & EG-AM-11 \\
\hline & & & EG-AM-18 & EG-AM-13 \\
\hline & & & EG-AM-23a & EG-AM-14 \\
\hline & & & EG-AM-24b & EG-AM-28 \\
\hline & & & EG-AM-45 & EG-AM-35a \\
\hline & & & EG-AM-59 & EG-AM-35b \\
\hline & & & EG-AM-65 & EG-AM-56 \\
\hline & & & EG-AM-67 & EG-AM-57 \\
\hline & & & EG-AM-70 & EG-AM-73 \\
\hline \multirow[t]{2}{*}{ Сpy-Py } & Potassic & $E G-A M-27$ & $E G-A M-43$ & \\
\hline & $\begin{array}{l}\text { Sodic, } \\
\text { overprinting } \\
\text { potassic }\end{array}$ & $E G-A M-29 b$ & $\begin{array}{l}E G-A M-15 \\
E G-A M-24 a\end{array}$ & \\
\hline Py > Cpy & $\begin{array}{l}\text { Sodic, } \\
\text { overprinting } \\
\text { potassic }\end{array}$ & $E G-A M-29 a$ & $E G-A M-30$ & \\
\hline
\end{tabular}

hessite) were analysed by wavelength-dispersive spectroscopy (WDS) using the electron microprobe (EPMA) at the University of California, Davis to quantitatively determine the compositions of each phase. An accelerating voltage of $15 \mathrm{kV}$, a beam current of 20nA and a counting time of $30 \mathrm{~s}$ were used.

The distribution of samples with regard to original lithology, alteration type and mineralisation type are listed in Table 2.

\section{Results}

\subsection{Petrography: Alteration}

All samples in this study have undergone potassic alteration, and some have been subjected to subsequent late stage albite-chlorite and sericite-quartz alteration (Table 2).

\subsubsection{Potassic alteration}

Potassic alteration comprises replacement of hornblende by sagenitic biotite, replacement of plagioclase by $\mathrm{K}$ feldspar along vein selvages and fractures, and significant recrystallisation of groundmass with fine crystalline, mosaic-textured quartz and fine crystalline secondary biotite. Sagenitic biotite (Fig. 2a) contains tiny oriented needles of titanite, which form through the exsolution of titanium.

\subsubsection{Sodic alteration}

Sodic alteration comprises replacement of biotite by chlorite and sulphides, and sparse formation of epidote. K-feldspar has rims of albite and plagioclase has irregular zoning (Fig. 2d, e). Feldspars, particularly plagioclase, are pervasively but not intensely sericitised. Titanite is associated with patches of chlorite. Calcite veins crosscut the assemblage, hosting anhedral chalcopyrite (Fig. 2b).

\subsubsection{Sericite-quartz alteration}

Sericite-quartz alteration comprises replacement of feldspars by sericite (fine-grained white mica), and may obliterate primary igneous rock texture, resulting in a groundmass of sericite and quartz (Fig. 2c, d). Plagioclase is commonly more intensely altered than $\mathrm{K}$ feldspar. Medium-crystalline, tabular muscovite may also be observed in patches or veins crosscutting a sericitised groundmass (Fig. 2f). Fine sericite replaces feldspar phenocrysts, and groundmass is commonly formed of fine sericite and quartz (SQ assemblage from Dilles and Einaudi, 1992). Sericite-quartz alteration is most common in the western portion of the deposit, which was originally shallower. Sericite from the Blue Hill part of the Ann-Mason deposit is mostly muscovite, with minor late-stage illite (Cohen, 2011), indicating that sericite-quartz alteration likely formed at $>300{ }^{\circ} \mathrm{C}$ (Halley et al., 2015). Moderate to intense sericitequartz alteration is associated with the presence of pyrite in the samples.

\subsection{Petrography: mineralisation}

Ore mineral assemblages in this study have been categorised by their sulphide mineralogy, on the basis of Dilles and Einaudi (1992).

\subsubsection{Chalcopyrite-bornite zone (Ccp-Bn)}

Sulphides in the Ccp-Bn zone are commonly multiphase (bornite and chalcopyrite), sub- to anhedral and hosted within quartz-rich veins. Sulphides rarely enclose quartz or epidote crystals (Fig. 3d). Sulphides may also be associated with secondary biotite within quartz veins. Chalcopyrite textures vary from comprising the majority of a multiphase sulphide to lamellae in a predominantly bornite crystal (Fig. 3a-d), and many of the dominantly chalcopyrite crystals have heavily pitted surfaces. Some multiphase sulphides include areas of tennantite on the edge of bornite (Fig. 3b). Single phase crystals of chalcopyrite and bornite are also common.

\subsubsection{Chalcopyrite-pyrite zone (Ccp-Py)}

Sulphides are dominantly anhedral chalcopyrite, typically as small crystals with pitted surfaces. Chalcopyrite is commonly disseminated through the groundmass, but may be hosted within quartz or calcite veins. Conversely, pyrite crystals are subhedral with smooth surfaces, and may contain small rounded inclusions of chalcopyrite, or be surrounded by interstitial chalcopyrite (Fig. 3f). Pyrite is commonly but not exclusively associated with patches of medium crystalline muscovite. Bornite is very rare, but when present is closely associated with chalcopyrite, and has a similarly anhedral shape and pitted surface.

\subsubsection{Pyrite $>$ chalcopyrite zone (Py $>C c p)$}

Pyrite is the dominant sulphide, is typically subhedral, with smooth surfaces and is concentrated in veins of medium crystalline, mosaic textured quartz. Subordinate chalcopyrite is anhedral with a pitted surface and is interstitial to pyrite, contained within pyrite, or as discrete crystals (Fig. 3e). Bornite is very rare, but where present is closely associated with chalcopyrite. Chalcopyrite commonly forms rims around pyrite crystals.

\subsection{Geochemistry}

Two metre assay data for each sample are given in Table 1, with mean values for each mineralisation zone in the final three rows. Copper is constant (on average) at $\sim 0.81 \mathrm{wt} \%$ between the Ccp-Bn and the CcpPy zones, but decreases to $0.36 \mathrm{wt} \%$ in the Py > Ccp zone, which is expected due to the relative paucity of $\mathrm{Cu}$-sulphide minerals in this zone. Gold increases slightly on average $(0.23 \mathrm{ppm}$ to $0.26 \mathrm{ppm}$ to $0.28 \mathrm{ppm})$ and silver sharply decreases on average ( $4.06 \mathrm{ppm}$ to $1.32 \mathrm{ppm}$ to 0.55 ppm) from the Ccp-Bn to the Ccp-Py zone to the Py > Ccp zone. The average $\mathrm{Ag} / \mathrm{Cu}$ ratio is highest in the Ccp-Bn zone (0.00053, compared to 0.00016 in the Ccp-Py and Py > Ccp zones).

Geochemical data for each sample are plotted against one another in Fig. 4. Using a Pearson Product-Moment Correlation for all samples together $(\mathrm{n}=30), \mathrm{Cu}$ and $\mathrm{Ag}$ show a strong positive relationship ( $\mathrm{r}$ value $=0.42)$, while $\mathrm{Cu}$ and $\mathrm{Au}(\mathrm{r}=0.16)$, and $\mathrm{Au}$ and $\mathrm{Ag}(\mathrm{r}=0.18)$ have a negligible relationship. Analysing the Ccp-Bn zone samples only ( $\mathrm{n}=$ 23), $\mathrm{Cu}$ has a moderate positive relationship with both $\mathrm{Au}(\mathrm{r}=0.20)$ and $\mathrm{Ag}(\mathrm{r}=0.38)$, and $\mathrm{Au}$ has a strong positive relationship with $\mathrm{Ag}(\mathrm{r}=$ $0.54)$. Correlation coefficients could not be calculated for the Ccp-Py and Py $>$ Ccp zones due to small number of samples $(n=5$ and $n=2$, 


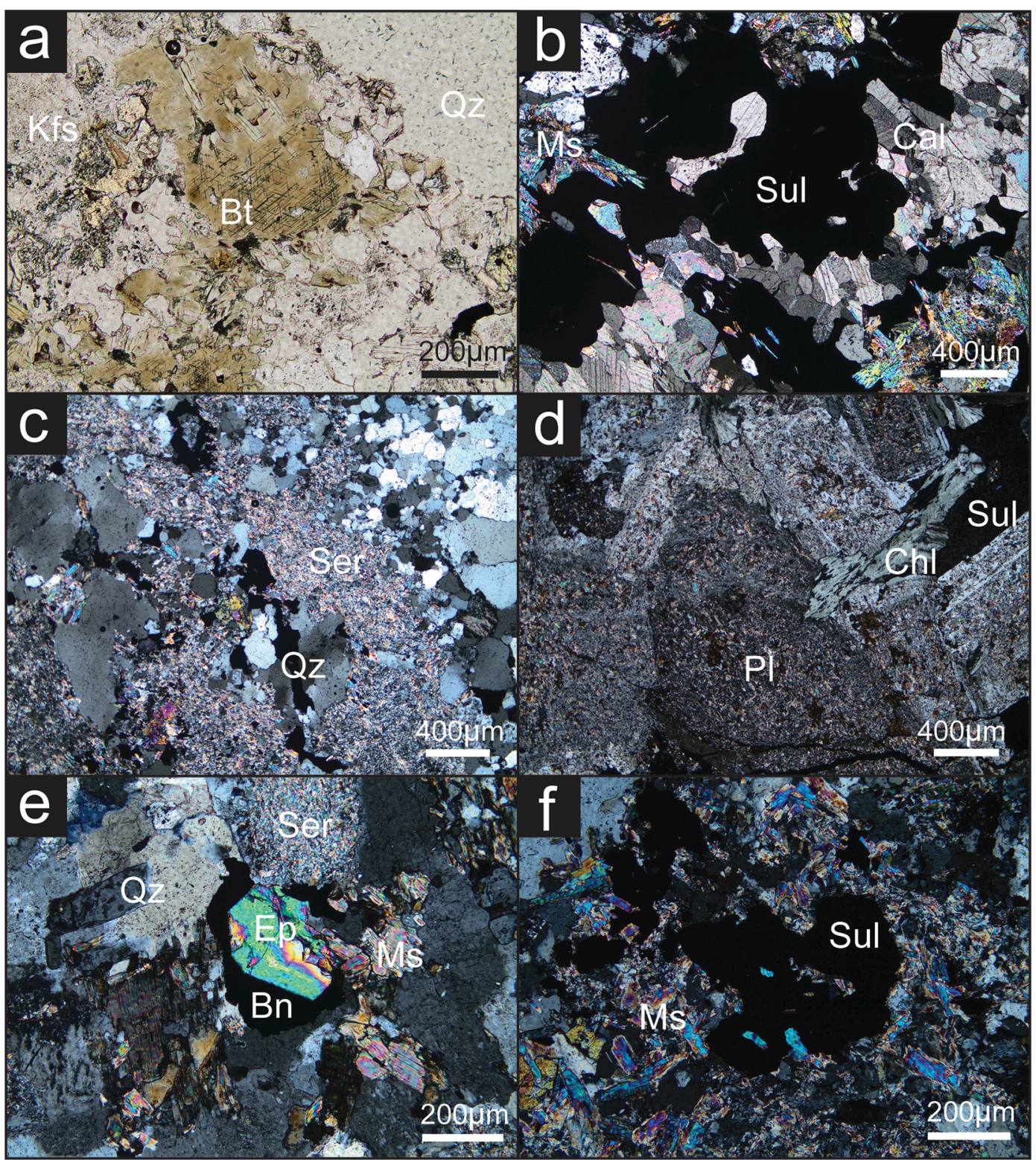

Fig. 2. Silicate alteration of the Ann Mason deposit. a) sagenitic biotite in EG-AM-15; b) Calcite and pyrite vein with muscovite in EG-AM-43; c) pervasive sericite (very fine muscovite) alteration cut by quartz veins in EG-AM-27; d) sericitised (altered to very fine muscovite) feldspars with chlorite and sulphide minerals in EGAM-43; e) bornite and chalcopyrite wrapping around epidote in association with sericite and muscovite in EG-AM-10; f) sulphide minerals with muscovite in EG-AM27. Abbreviations: Kfs K-feldspar, Bt biotite, Qz quartz, Ms muscovite, Sul sulphide minerals, Cal calcite, Ser sericite, Pl plagioclase, Chl chlorite, Ep epidote, Bn bornite.

respectively).

\subsection{Visible deportment of gold and silver}

Trace concentrations of gold and silver in porphyry deposits are commonly present both as microparticles of gold- and silver-bearing minerals (commonly native gold or electrum), and as 'invisible' gold and silver (Arif and Baker, 2004; Reich et al., 2013), which is structurally held within the crystal lattices of sulphide minerals. An unpublished study at Ann-Mason (J. Dilles pers. comm.) found a mean of $314 \mathrm{ppm} \mathrm{Ag}$ in bornite, 47-75 ppm Ag in chalcopyrite and $23 \mathrm{ppm} \mathrm{Ag}$ in pyrite, but Au was below the detection limit (7 ppm) in the sulphides. No data have previously been collected on the precious metals at Ann-Mason that are hosted within gold- and silver-bearing microparticles, which is the focus of this paper.

Thirty samples from Ann-Mason were analysed by SEM, yielding analyses of a total of 438 individual precious metal minerals. A total of 90 gold-bearing grains (in 29 samples) and 389 silver-bearing grains (in 30 samples) were analysed (Fig. 5). Gold is hosted predominantly in the form of electrum, with subordinate occurrences of Au-Ag telluride and native gold. The majority of silver is hosted as silver telluride minerals (most commonly hessite, but also Au-Ag, Pd-Ag or Ag-Bi tellurides), with subordinate electrum and silver selenides. Ten occurrences of Pd minerals were observed in six samples, 29 occurrences of Bi minerals in six samples, and six occurrences of $\mathrm{Hg}$ minerals in three samples.

Precious metal-bearing mineral species were mostly associated with sulphide minerals, either within or on the edge of sulphide grains, or as isolated grains hosted within silicate minerals. From a total of 438 precious metal-bearing minerals analysed, $89 \%$ were associated with either bornite, chalcopyrite or pyrite, with $68 \%$ associated with bornite, $16 \%$ associated with chalcopyrite, $6 \%$ associated with pyrite and $2 \%$ associated with tennantite, while $9 \%$ were hosted as 'free' grains 


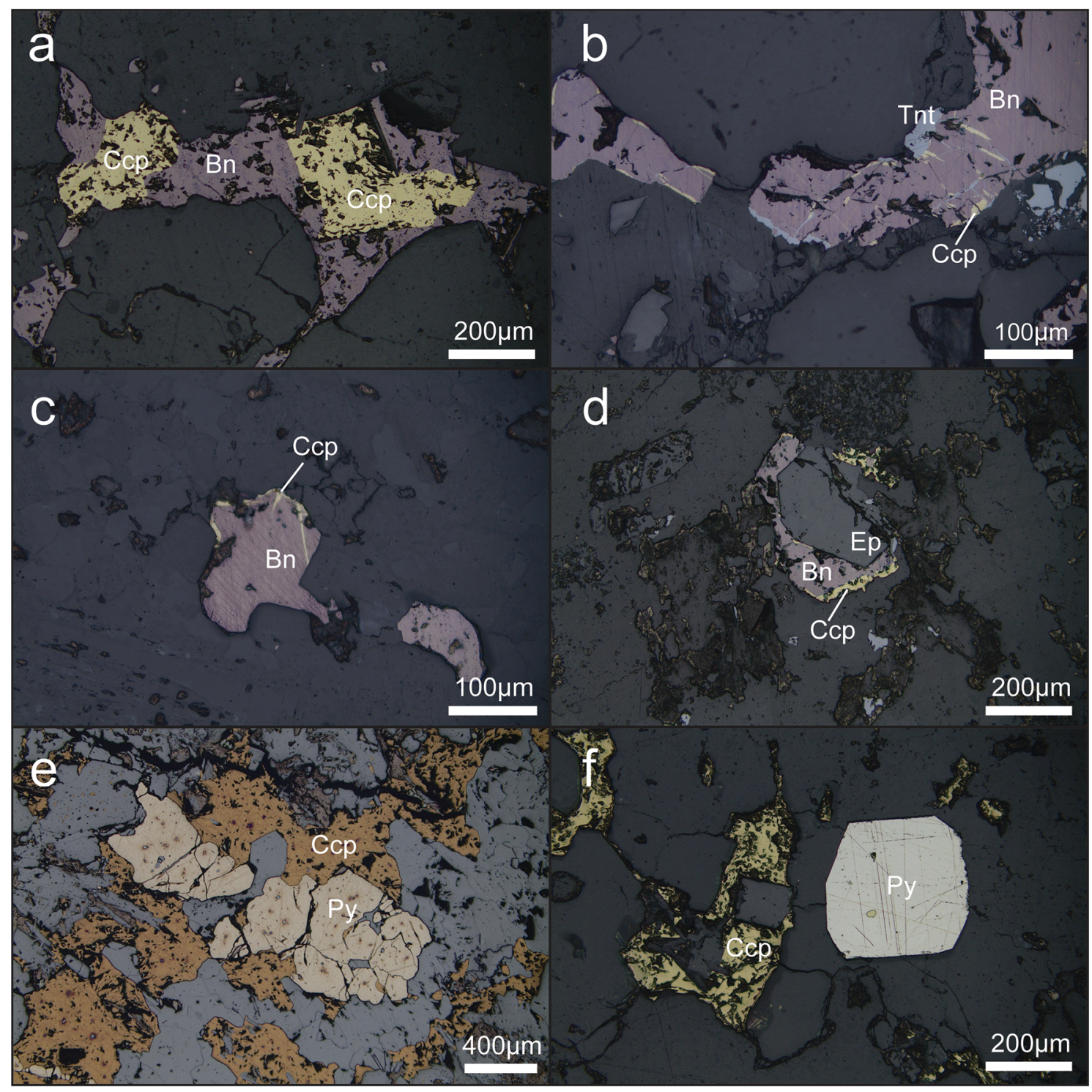

Fig. 3. Sulphide mineralisation of the Ann Mason deposit. a) bornite surrounding chalcopyrite in EG-AM-01a in the Ccp-Bn zone; b and c) chalcopyrite lamellae in bornite edged by tennantite in EG-AM-08 in the Ccp-Bn zone; d) bornite edged by chalcopyrite surrounding epidote in EG-AM-10 in the Ccp-Bn zone; e) chalcopyrite interstitial to pyrite containing chalcopyrite inclusions in EG-AM-43 in the Ccp-Py zone; f) chalcopyrite near euhedral pyrite containing a chalcopyrite inclusion in EG-AM-27 in the Ccp-Py zone. Abbreviations: Ccp chalcopyrite, Bn bornite, Tnt tennantite, Ep epidote, Py pyrite.

isolated within silicate minerals (Fig. 6), including potassium feldspar and quartz. Almost all microparticles are located along the edges of sulphides, along fractures or with microporosity within sulphides.

Within the Ccp-Bn zone, $80 \%$ of precious metal minerals are hosted within or on the edge of bornite, $8 \%$ are hosted by chalcopyrite, $2 \%$ by tennantite and $9 \%$ by silicate minerals. In the Ccp-Py zone, $69 \%$ are hosted by chalcopyrite, $2 \%$ by bornite, $18 \%$ by pyrite and $10 \%$ by silicates. In the Py $>$ Ccp zone, $26 \%$ are hosted by chalcopyrite and $74 \%$ by pyrite (Fig. 6).

Precious metal deportment is consistent across all original rock lithologies, confirming that the composition of the pre-mineralisation rock is immaterial to the final precious metal mineral assemblage.

The occurrence and characteristics of different precious metal minerals are summarised in Table 3 and described individually below. This research was carried out through semi-quantitative SEM analysis, so only tentative mineral identifications have been made. In some cases further EPMA analyses would be required to distinguish between several mineral options, but the majority of the particles were too small to accurately determine composition.

\subsubsection{Electrum and native gold}

Native gold and native silver are defined on a compositional continuum, with native gold comprising $\mathrm{Ag}_{0-0.65} \mathrm{Au}_{1-0.35}$ and native silver comprising $\mathrm{Ag}_{0.65-1} \mathrm{Au}_{0.35-0}$ (Palyanova, 2020). Due to the qualitative and semi-quantitative nature of our analysis, in this study we have classed microparticles containing solely $\mathrm{Au}$ as native gold, and microparticles containing even a little silver as electrum. By this definition, we have only observed three microparticles of native gold, but really we have only observed three microparticles of high fineness native gold, and much of the observed 'electrum' should likely be classified as native gold of lower fineness.

Electrum is predominantly observed in the Ccp-Bn zone, with 69 of the 72 electrum occurrences in this zone. Electrum is generally globular in shape and ranges in size from 1 to $13.5 \mu \mathrm{m}$. It is most commonly hosted within bornite (Fig. 7a, e). One EPMA analysis (with a wt\% total of only $94.5 \%$ ) gave a chemical composition of 63.9 atomic \% Au, 24.6 atomic \% Ag, 9.8 atomic $\% \mathrm{Cu}$ and 1.8 atomic \% S (see Table 4), identifying it as cupric electrum.

Native gold: three grains are observed in the samples analysed. All are 

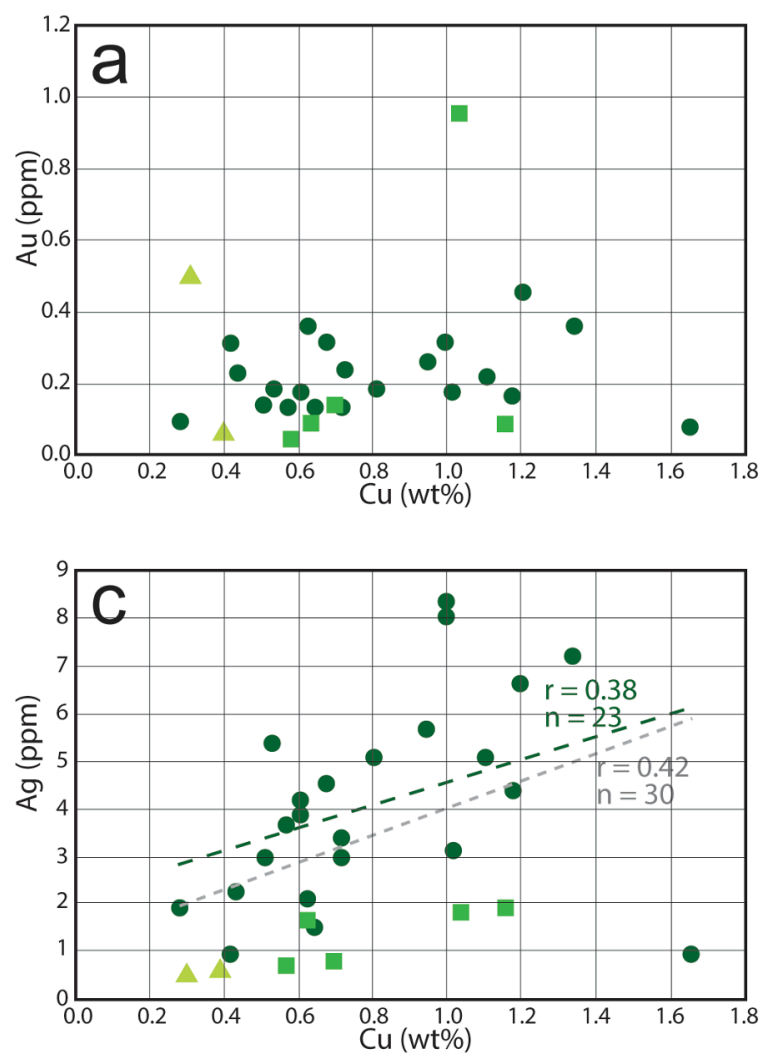

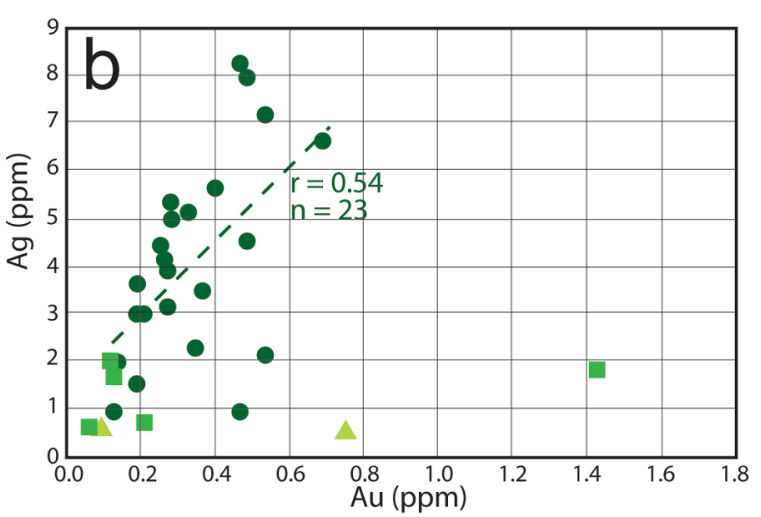

Chalcopyrite-Bornite

Chalcopyrite-Pyrite

Pyrite>Chalcopyrite

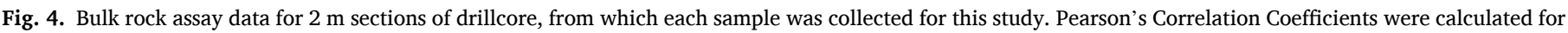

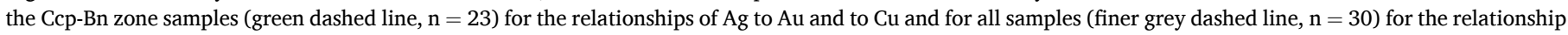
between $\mathrm{Ag}$ and $\mathrm{Cu}$. No relationships were found between $\mathrm{Au}$ and $\mathrm{Cu}$, or for all samples between $\mathrm{Ag}$ and $\mathrm{Au}$.

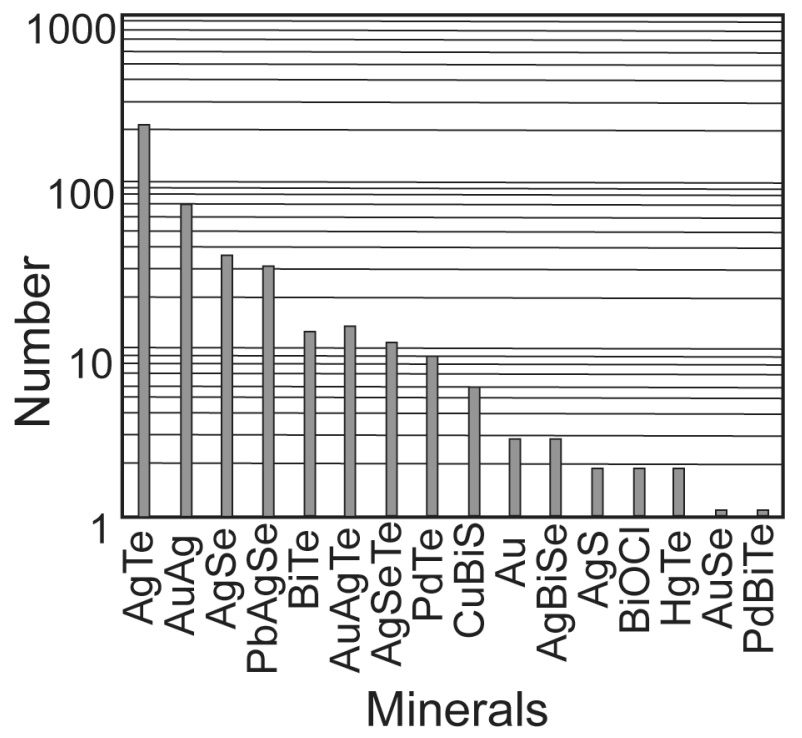

Fig. 5. Frequency of microparticle mineral analyses observed.

associated with sericitic alteration, and are present as round blebs. In the Py $>$ Ccp zone, native gold ( $\mathrm{n}=2 ; 3.4$ and $9.4 \mu \mathrm{m}$ diameter) is hosted within pyrite which is associated with muscovite, mosaic quartz, sericitised K-feldspar and chlorite (Fig. $8 \mathrm{c}$, h). In the Ccp-Bn zone, native gold $(\mathrm{n}=1 ; 6.4 \mu \mathrm{m})$ is hosted within secondary K-feldspar and mosaic quartz. One EPMA analysis of native gold from the Py > Ccp zone gave a composition of 88.5 atomic \% Au and 11.5 atomic \% Fe (see Table 4).

\subsubsection{Telluride minerals}

Telluride minerals are most prevalent in the Ccp-Bn zone, especially hessite $\left(\mathrm{Ag}_{2} \mathrm{Te}\right)$, with 210 of the 216 hessite occurrences being observed in the Ccp-Bn zone. Over $85 \%$ of the hessite present in the Ccp-Bn zone is hosted by bornite: $36 \%$ on the edges of crystals, and $49 \%$ within crystals. In the Ccp-Bn zone, only $7 \%$ are associated with chalcopyrite crystals, and $9 \%$ are hosted as isolated grains within silicate minerals including plagioclase, biotite and potassium feldspar. When present within a sulphide crystal, hessite commonly has either an acicular or a rounded habit, and grains range in size from 0.5 to $27.2 \mu \mathrm{m}$ (Fig. $7 \mathrm{~b}, \mathrm{~d}, \mathrm{f}$ ). Based on the results of EPMA analysis (see Table 4), the contents of Ag and Te in hessite are 64.1 atomic $\%$ and 35.9 atomic $\%$ respectively. This gives a composition of $\mathrm{Ag}_{1.8} \mathrm{Te}$, which has a slightly lower ratio of $\mathrm{Ag}$ to $\mathrm{Te}$ than stoichiometric proportions of $\mathrm{Ag}_{2} \mathrm{Te}$. Hessite is observed in composite microparticles with Au-Ag-Te (Ccp-Bn, Fig. 81) and with Bi-Te (Py > Ccp, Fig. 8g).

Au-Ag-Te (possibly sylvanite, (Au,Ag) ${ }_{2} \mathrm{Te}_{4}$; muthmannite, $\mathrm{AuAgTe}_{2}$; krennerite, $\mathrm{Au}_{3} \mathrm{AgTe}_{8}$; or petzite, $\mathrm{Ag}_{3} \mathrm{AuTe}_{2}$ ) shows a similar distribution to hessite within the Ccp-Bn zone $(\mathrm{n}=11)$. Grains range in size from 0.7 to $10.7 \mu \mathrm{m}$ (Fig. 8k, 1).

Pd- and Pd-Bi-bearing telluride species are only present in the Ccp-Bn zone, predominantly hosted within or on the edge of bornite or tennantite, likely as merenskyite $\left((\mathrm{Pd}, \mathrm{Pt})(\mathrm{Bi}, \mathrm{Te})_{2}\right)$. Merenskyite crystals (n =9) range in size from 1 to $10.8 \mu \mathrm{m}$ (Fig. 8i). Only one Bi-bearing merenskyite grain was observed, measuring $3 \mu \mathrm{m}$ and hosted in bornite. Merenskyite was observed in a composite microparticle with clausthalite (PbSe) in the Ccp-Bn zone (Fig. 8j).

Bi-Te ranges in size from 1.7 to $18 \mu \mathrm{m}(\mathrm{n}=13)$ and is hosted within or on the edge of pyrite crystals, located within the Py > Ccp zone (Fig. $8 \mathrm{~b}, \mathrm{~d}, \mathrm{e}, \mathrm{g})$. It is also observed $(\mathrm{n}=4)$ isolated within silicates in the $\mathrm{Ccp}-\mathrm{Bn}$ zone. Bi-Te is only observed in samples where native gold is also present. An EPMA analysis with very poor total wt $\%$ (54\%) indicated a 


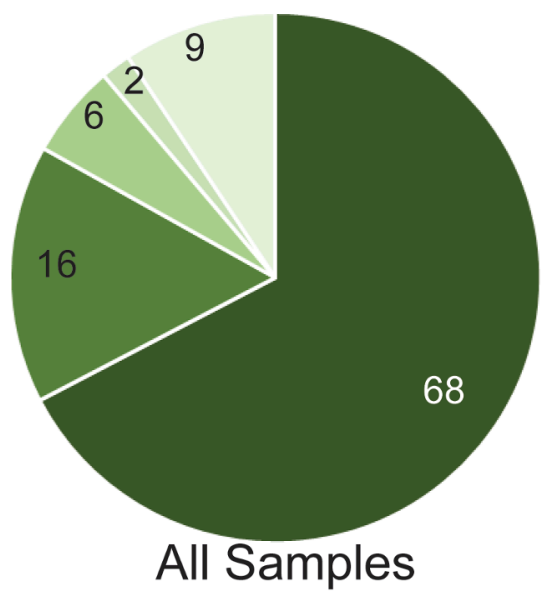

Key

Bornite-hosted

Chalcopyrite-hosted

Pyrite-hosted

Tennantite-hosted

Silicate-hosted
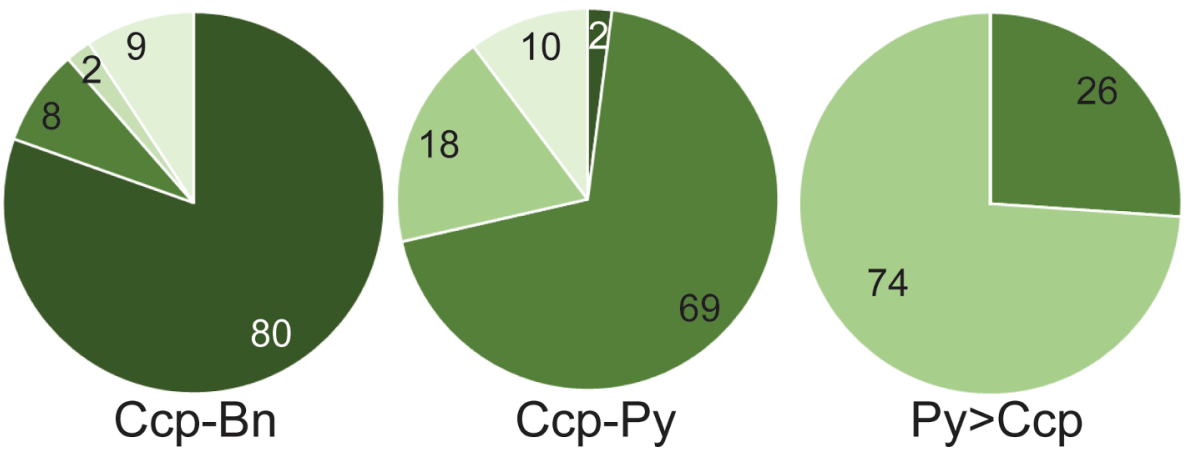

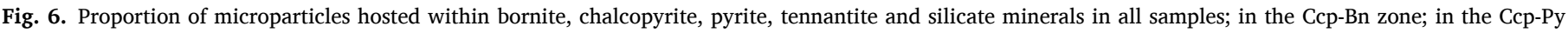
zone; and in the Py > Ccp zone.

Table 3

Qualitative SEM analytical results, including type of microparticle and location in relation to host mineral.

\begin{tabular}{|c|c|c|c|c|c|c|c|c|c|}
\hline Analysis & Possible Mineral name & In $B n$ & On Bn & In $C c p$ & On Ccp & In Py & On Py & In Tn & Free \\
\hline $\mathrm{Ag}-\mathrm{Te}$ & Hessite $\left(\mathrm{Ag}_{2} \mathrm{Te}\right)$ & 102 & 76 & 8 & 10 & 1 & & 4 & 19 \\
\hline $\mathrm{Ag}-\mathrm{Au}$ & Electrum (Au-Ag alloy) & 35 & 23 & 5 & 1 & 2 & & 2 & 4 \\
\hline $\mathrm{Au}-\mathrm{Ag}-\mathrm{Te}$ & $\begin{array}{l}\text { Petzite }\left(\mathrm{Ag}_{3} \mathrm{AuTe} \mathrm{C}_{2}\right) \text {, Sylvanite }\left((\mathrm{Ag}, \mathrm{Au}) \mathrm{Te}_{2}\right) \\
\text { Muthmannite }\left(\mathrm{AuAgTe}_{2}\right) \\
\text { Krennerite }\left(\mathrm{Au}_{3} \mathrm{AgTe}_{8}\right)\end{array}$ & 4 & 4 & 3 & 1 & & & & 2 \\
\hline $\mathrm{Ag}-\mathrm{Se}$ & Naumannite $\left(\mathrm{Ag}_{2} \mathrm{Se}\right)$ & 3 & 5 & 5 & 15 & 7 & & & 1 \\
\hline $\mathrm{Pb}-\mathrm{Ag}-\mathrm{Se}$ & Naumannite $\left((\mathrm{Ag}, \mathrm{Pb})_{2} \mathrm{Se}\right)$ & 4 & 24 & & 4 & & & & \\
\hline $\mathrm{Bi}-\mathrm{Te}$ & Tellurobismuthite $\left(\mathrm{Bi}_{2} \mathrm{Te}_{3}\right)$, Tetradymite $\left(\mathrm{Bi}_{2} \mathrm{TeS}_{2}\right)$ & & & & 1 & 3 & 6 & & 4 \\
\hline Ag-Te-Se & Kurilite $\left(\mathrm{Ag}_{8} \mathrm{Te}_{3} \mathrm{Se}\right)$ & & 1 & 4 & 3 & 1 & 1 & & 1 \\
\hline Pd-Te & Merenskyite $\left(\mathrm{Pd}(\mathrm{Bi}, \mathrm{Te})_{2}\right)$ & 4 & 3 & & & & & & 2 \\
\hline Pd-Bi-Te & Merenskyite $\left(\mathrm{Pd}(\mathrm{Bi}, \mathrm{Te})_{2}\right)$ & 1 & & & & & & & \\
\hline $\mathrm{Au}$ & Native gold & & & & & 2 & & & 1 \\
\hline $\mathrm{Ag}$ & Native silver & & & & 2 & & & & \\
\hline $\mathrm{Hg}-\mathrm{Te}$ & Coloradpite (HgTe) & 1 & & & 1 & & 2 & & 1 \\
\hline $\mathrm{Ag}-\mathrm{Bi}-\mathrm{Te}$ & Volynskite $\left(\mathrm{AgBiTe}_{2}\right)$, & & & & 1 & & 1 & & \\
\hline Au-Se & (unnamed) & & & & & & & & 1 \\
\hline $\mathrm{Bi}-\mathrm{Cl}$ & Bismoclite (BiOCl) & & & & & & & & 2 \\
\hline $\mathrm{Cu}-\mathrm{Bi}-\mathrm{S}$ & Wittichenite $\left(\mathrm{Cu}_{3} \mathrm{BiS}_{3}\right)$ & 3 & 2 & 1 & & & & & \\
\hline
\end{tabular}

geochemical composition of Bi2Te (see Table 4), which does not match the composition of any named mineral, but this composition is unreliable due to poor analytical totals. Further analysis is required to determine the mineral name, but this was outside the scope of this study.

Hg-bearing telluride species (likely Coloradoite HgTe) is 2.4-6.7 $\mu \mathrm{m}$ $(\mathrm{n}=2)$ and is hosted within chalcopyrite filling a fracture through pyrite (Fig. 8b) or within silicates close to a sulphide crystal. This mineral is only observed within the Ccp-Py or the Py > Ccp zones. Hg-Te is observed in composite microparticles with Bi-Te in the Py > Ccp zone.

\subsubsection{Selenide minerals}

Selenide minerals are 3.5 times more prevalent in the Ccp-Py zone (n
$=33$ in 3 samples) than in the Ccp-Bn zone ( $\mathrm{n}=37$ in 12 samples), although the former is dominated by Ag-Se and the latter by Pb-Ag-Se crystals.

$\mathrm{Ag}$-Se (likely naumannite, $\mathrm{Ag}_{2} \mathrm{Se}$ ) ranges in size from 1 to $14.8 \mu \mathrm{m}$ (n $=37$ ) and is dominantly located on the edge of chalcopyrite (Fig. 8a, f). Of all the Ag-Se observed, 27\% was found in the Ccp-Bn zone and the remaining $73 \%$ was in the Ccp-Py zone.

$\mathrm{Pb}-\mathrm{Ag}$-Se (composition does not match any known mineral, but likely naumannite with $\mathrm{Pb}$ substitution for $\mathrm{Ag}$ ) ranges in size from 1 to $8 \mu \mathrm{m}$ (n $=31$ ) and is located almost entirely on the edge of bornite crystals (Fig. 8f, j). Of the Pb-Ag-Se minerals, $16 \%$ was in the Ccp-Py zone and the remainder was in the Ccp-Bn zone. 


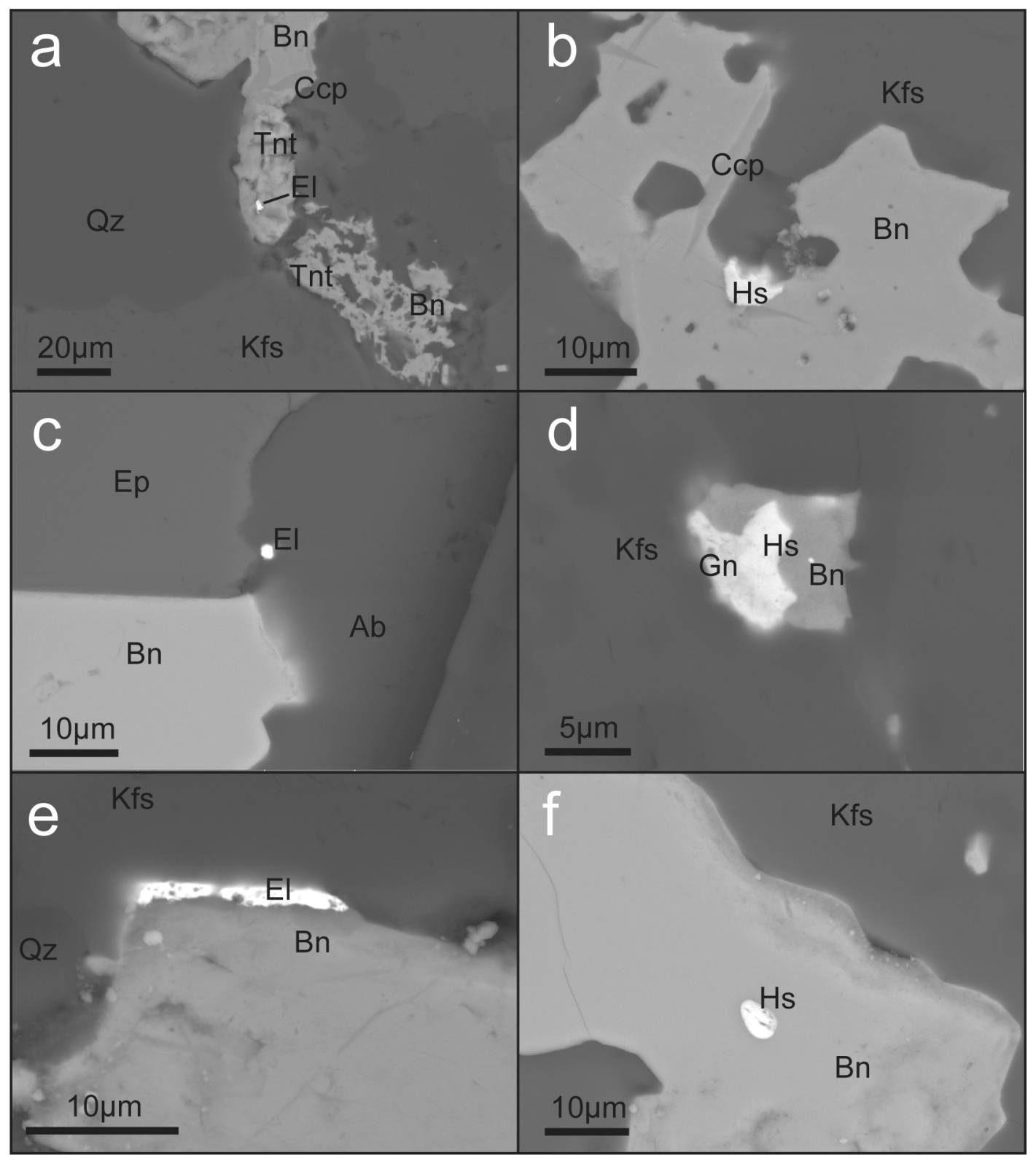

Fig. 7. Representative photomicrographs of hessite and electrum in the Ann Mason deposit. a) electrum hosted by tennantite in EG-AM-35b; b) hessite hosted by bornite with chalcopyrite lamellae in EG-AM-35b; c) electrum hosted by albite and epidote near bornite in EG-AM-57; d) multiphase particle of hessite and galena hosted by bornite within K-feldspar in EG-AM-35b; e) electrum on the edge of bornite and K-feldspar in EG-AM-57; f) hessite in bornite in EG-AM-57. Abbreviations: Bn bornite, Ccp chalcopyrite, Tnt tennantite, Gn galena, El electrum, Hs hessite, Qz quartz, Kfs K-feldspar, Ep epidote, Ab albite.

$\mathrm{Ag}$-Te-Se (likely kurilite, $\mathrm{Ag}_{8} \mathrm{Te}_{3} \mathrm{Se}$ ) is mostly associated on or within chalcopyrite within the Ccp-Py zone. Crystals range from 2.1 to $7.6 \mu \mathrm{m}$ $(\mathrm{n}=10)$

Au-Se: only one AuSe crystal $(4.3 \mu \mathrm{m})$ was observed in the Ccp-Py zone isolated in silicates (composition does not match any named mineral).

$\mathrm{Ag}$-Bi-Se (possibly bohdanowiczite $\mathrm{AgBiSe}_{2}$ ) was observed in the Ccp-Bn zone, ranging in size from 4.7 to $1.2 \mu \mathrm{m}(\mathrm{n}=3)$ and hosted by chalcopyrite.

Clausthalite (PbSe) was commonly observed throughout the Ccp-Bn zone, but was not specifically recorded and measured in this study (Fig. 8a, j).

\subsubsection{Other minerals}

Two occurrences of acanthite $\left(\mathrm{Ag}_{2} \mathrm{~S}\right)$ were observed in the Ccp-Py and $\mathrm{Py}>\mathrm{Ccp}$ zones. Crystals ranged in size from 3 to $4.7 \mu \mathrm{m}$ and were associated with chalcopyrite.

Bi-bearing copper sulphides (likely Wittichenite $\mathrm{Cu}_{3} \mathrm{BiS}_{3}$, see Table 4) are observed in the Ccp-Bn zone $(n=6)$, associated with bornite ( $\mathrm{n}=5$ ) and ranging in size from 26.4 to $5.5 \mu \mathrm{m}$. One $2 \mu \mathrm{m}$ crystal is hosted within chalcopyrite.

Bismoclite (BiOCl) ranges in size from 3.8 to $4 \mu \mathrm{m}$ and is observed isolated in silicates within two samples from the Ccp-Py zone.

\section{Discussion}

\subsection{Mineralisation and alteration}

Previous research has described the association of $\mathrm{Cu}$-sulfide bearing assemblages with potassic alteration (Dilles and Einaudi, 1992). Our petrographic results support the association of the chalcopyrite-bornite assemblage with potassic alteration, and find that the majority of 
Table 4

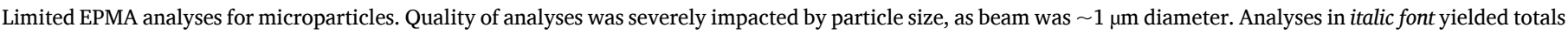
$<99 \mathrm{wt} \%$.

\begin{tabular}{|c|c|c|c|c|c|c|c|c|c|c|c|c|c|}
\hline & Sample & 45 & 30 & 43 & 30 & 30 & 45 & 45 & 57 & 57 & 45 & 57 & 57 \\
\hline & Area & 4 & 2 & 16 & 15 & 11 & 12 & 12 & 16 & 39 & 12 & 3 & 35 \\
\hline \multirow[t]{10}{*}{ Wt $\%$} & $\mathrm{Fe}$ & 0 & 3.53 & 3.015 & 0.92 & 1.904 & 0 & 0 & 0 & 0 & 0 & 0.119 & 0.072 \\
\hline & $\mathrm{Cu}$ & 0 & 0 & 3.524 & 0 & 0.625 & 0 & 0 & 0 & 3.684 & 34.983 & 0.555 & 0.444 \\
\hline & $\mathrm{Pb}$ & 0 & 0 & 78.561 & 0 & 0 & 0 & 0 & 0 & 0 & -0.082 & 76.18 & 72.503 \\
\hline & $\mathrm{Au}$ & 0 & 95.501 & 0 & 0 & 0 & 2.796 & 0 & 0 & 74.731 & 0 & 0 & 0 \\
\hline & $\mathrm{Ag}$ & 60.062 & 0 & 0 & 0.038 & 43.682 & 53.618 & 51.246 & 53.477 & 15.777 & 0 & 0 & 0 \\
\hline & $\mathrm{Bi}$ & 0 & 0 & 0 & 40.701 & 3.245 & 0 & 0 & 0 & 0 & 41.308 & 0 & 0 \\
\hline & $S$ & 0 & 0 & 14.891 & 0 & 0 & 0 & 0 & 0 & 0.335 & 18.634 & 6.34 & 5.232 \\
\hline & $\mathrm{Te}$ & 39.767 & 0 & 0 & 12.397 & 28.39 & 33.026 & 33.595 & 35.31 & 0 & 0 & 0 & 0 \\
\hline & $\mathrm{Se}$ & 0 & 0 & 0 & 0 & 0 & 0 & 0 & 0 & 0 & 0 & 11.645 & 14.074 \\
\hline & Total & 99.828 & 99.031 & 99.991 & 54.056 & 77.846 & 89.441 & 84.841 & 88.787 & 94.527 & 94.924 & 94.838 & 92.324 \\
\hline \multirow[t]{12}{*}{ Atomic\% } & $\mathrm{Fe}$ & & 11.533 & 5.664 & 5.335 & 4.964 & & & & & & 0.295 & 0.184 \\
\hline & $\mathrm{Cu}$ & & & 5.818 & & 1.431 & & & & 9.758 & 41.423 & 1.207 & 0.998 \\
\hline & $\mathrm{Pb}$ & & & 39.782 & & & & & & & -0.03 & 50.799 & 50.016 \\
\hline & $\mathrm{Au}$ & & 88.467 & & & & 1.843 & & & 63.863 & & & \\
\hline & $\mathrm{Ag}$ & 64.114 & & & 0.114 & 58.953 & 64.547 & 64.343 & 64.177 & 24.618 & & & \\
\hline & $\mathrm{Bi}$ & & & & 63.082 & 2.26 & & & & & 14.873 & & \\
\hline & $\mathrm{S}$ & & & 48.735 & & & & & & 1.761 & 43.734 & 27.322 & 23.324 \\
\hline & $\mathrm{Te}$ & 35.886 & & & 31.468 & 32.391 & 33.61 & 35.657 & 35.823 & & & & \\
\hline & $\mathrm{Se}$ & & & & & & & & & & & 20.377 & 25.478 \\
\hline & Total & 100 & 100 & 100 & 100 & 100 & 100 & 100 & 100 & 100 & 100.03 & 100 & 100 \\
\hline & & $\mathrm{Ag} 2 \mathrm{Te}$ & $\mathrm{Au}$ & $\mathrm{PbS}$ & Bi2Te & Ag2Te & Ag2Te & Ag2Te & Ag2Te & $A u 6 A g 2 C u$ & BiCu4S4 & $\mathrm{Pb} 2 \mathrm{SSe}$ & Pb2SSe \\
\hline & & Hessite & Native Gold & Galena & unnamed & Hessite & Hessite & Hessite & Hessite & Cupric electrum & Wittichenite & Selenian Galena & Selenian Galena \\
\hline
\end{tabular}

precious metal microparticles are also hosted by bornite within this assemblage, as also seen at Elatsite and Assarel deposits in Bulgaria (Cioacă et al., 2020).

\subsubsection{Formation of $C c p-B n$ Assemblages:}

Bornite and chalcopyrite are commonly closely associated with one another in the Ccp-Bn zone, typically with one as a rim around the other (Fig. 3a,d), or as chalcopyrite lamellae within bornite (Fig. 3b,c). Experimental studies over the past few decades have shown that it is difficult to decipher the crystallisation sequence from sulphide textures, as the textures derived from exsolution of chalcopyrite from bornite (Brett, 1964; Durazzo and Taylor, 1982) and those derived from the hydrothermal alteration of bornite to chalcopyrite look very similar (Schouten, 1934; Amcoff, 1988; Zhao et al., 2014; Li et al., 2018, 2020). Porphyry ccp-bn assemblages are typically attributed to precipitation of bornite solid solution from a hydrothermal fluid at temperatures of 350-700 ${ }^{\circ} \mathrm{C}$ (Sillitoe, 2010; Redmond et al., 2004; Wilson et al., 1980; Rusk et al., 2008), with subsequent solid-state exsolution of chalcopyrite lamellae and rims during annealing and recrystallisation as the rocks cool. However, the majority of experimental studies investigating exsolution have been run under dry conditions, which are not representative of conditions in porphyry systems.

Experiments conducted by Zhao et al (2014) have shown that bornite-digenite solid solution (bdss) can form through the interaction of chalcopyrite with hydrothermal fluids at temperatures between 250 and $320{ }^{\circ} \mathrm{C}$. Replacement occurs at the boundaries of chalcopyrite and proceeds inwards towards the crystal core (e.g. Fig. 3a), producing textures similar to those seen in the Ccp-Bn mineralisation zone at Ann-Mason (e. g. Li et al., 2020, 2018; Zhao et al., 2014), showing a sharp reaction front between a chalcopyrite core rimmed by bdss. These textures suggest that the dissolution of chalcopyrite is accompanied by the precipitation of $b d s s$ through interface coupled dissolution reprecipitation (ICDR) reactions, facilitated by micropores within the sulphide crystals. It is likely that the same processes also occur between 350 and $700{ }^{\circ} \mathrm{C}$ (Sillitoe, 2010), the typical temperature range of porphyry $\mathrm{Cu}$ deposition as determined by fluid inclusions, but these studies have not yet been undertaken, and there is as yet no diagnostic way to show whether chalcopyrite or bornite crystallised first from the fluids.

Bornite forms from bdss through recrystallisation (Zhao et al., 2014), which also allows annealing of micropores in the bornite crystal structure. Experiments by Li et al. (2018) showed that the exsolution of chalcopyrite lamellae from bornite-digenite solid solution (bdss) is catalysed by annealing of fluid-filled micropores in the $b d s s$ at $150{ }^{\circ} \mathrm{C}$. This process produces the same exsolution textures as produced under dry conditions. Given the hydrothermal conditions under which porphyry deposits form, it is likely that a hydrothermal fluid was directly involved in the exsolution of chalcopyrite from bornite at Ann-Mason.

We therefore propose that the bdss initially precipitated at high temperature $\left(>400{ }^{\circ} \mathrm{C}\right)$ from the hydrothermal fluids that produced the potassic alteration. During annealing chalcopyrite needles and rims exsolved from the bdss, mediated by the fluids held within the micropores in the sulphide minerals (Li et al., 2018). The remaining bdss recrystallised to bornite, producing the textures observed in Fig. 3a-d.

\subsubsection{Formation of Ccp-Py and Py > Ccp assemblages:}

As the Ccp-Py and Py > Ccp assemblages only appear to differ in their proportions of pyrite and chalcopyrite (possibly due to the small number of samples from these zones), they will be discussed together. Both assemblages are associated with moderate to intense sericitic alteration. In the intensely sericitised samples primary igneous texture is mostly obliterated and the groundmass replaced by fine crystalline quartz and sericite. Pyrite is also commonly in association with fine muscovite crystals in some samples, but there is no clear correlation between proportion of pyrite and intensity of sericitisation.

Dilles and Einaudi (1992) noted that the relatively sparse chalcopyrite + pyrite assemblage observed in sodic rocks contrasts with the abundant chalcopyrite + bornite assemblage observed in potassic rocks, and suggested that sodic alteration may have caused $\mathrm{Cu}$-loss and the removal of $\mathrm{Cu}$ upwards to precipitate in veins containing chalcopyrite and epidote. Our data are consistent with Cu-loss from the Ccp-Py and Py $>$ Ccp zones, as chalcopyrite is observed as fine disseminated crystals throughout the groundmass in both the Ccp-Py and the Py > Ccp zones (Fig. 3e,f), whereas in the Ccp-Bn zone it is more commonly observed as coarser crystals in quartz veins. Chalcopyrite is also commonly present in the Ccp-Py and Py > Ccp zones as small inclusions of chalcopyrite within pyrite crystals and as coarser, anhedral chalcopyrite surrounding subhedral pyrite. Chalcopyrite and bornite in all three zones is pitted in appearance, likely due to partial dissolution during $\mathrm{Cu}$ remobilisation. 


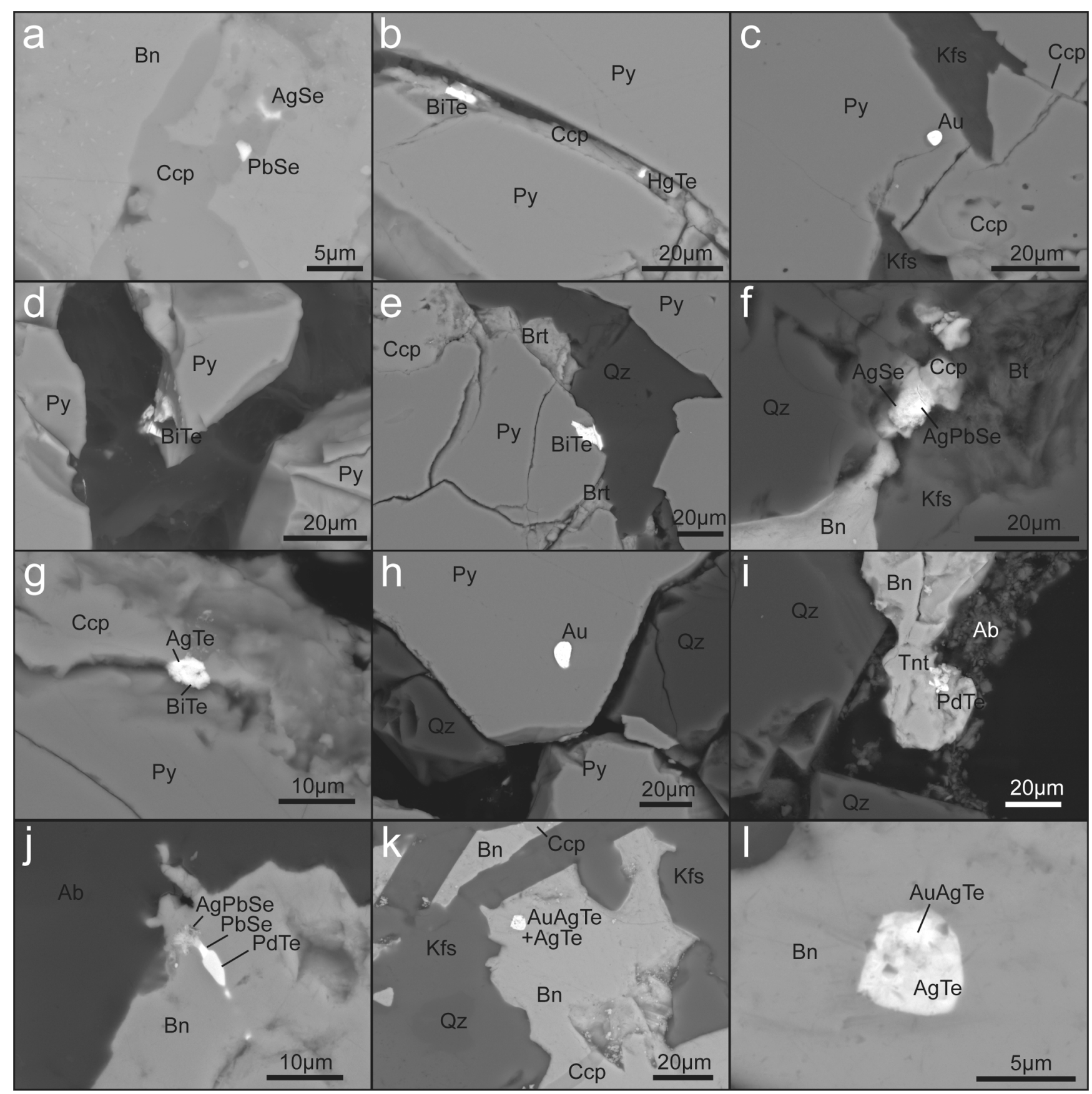

Fig. 8. Representative photomicrographs of microparticles in the Ann Mason deposit. a) PbSe and AgSe in chalcopyrite within bornite in EG-AM-73; b) Hg- and Bitellurides in chalcopyrite filling a fracture through pyrite in EG-AM-30; c) Native gold in pyrite cut with chalcopyrite-filled fractures in EG-AM-30; d) Bi-telluride on the edge of pyrite in EG-AM-30; e) Bi-telluride in the edge of pyrite associated with baryte, chalcopyrite and quartz in EG-AM-30; f) Multiphase particle of AgSe and $\mathrm{AgPbSe}$ between chalcopyrite and bornite associated with biotite in EG-AM-35a; g) Multiphase particle of hessite and Bi-telluride between bornite and chalcopyrite in EG-AM-30; h) Native gold in pyrite in EG-AM-30; i) Merenskyite in tennantite on the edge of bornite in EG-AM-35a; j) Multiphase particle of merenskyite, clausthalite ( $\mathrm{PbSe}$ ) and AgPbSe in bornite in EG-AM-35a; $\mathrm{k}, 1$ ) Multiphase particle of AuAgTe and hessite in bornite with chalcopyrite lamellae in EG-AM-57. Abbreviations: Bn bornite, Ccp chalcopyrite, Py pyrite, Kfs K-feldspar, Brt baryte, Qz quartz, Bt biotite, Ab albite.

Pyrite is present in the Ccp-Py and the Py > Ccp zones as subhedral crystals with a smooth surface, commonly associated with fine muscovite. This texture could be interpreted as precipitation of subhedral pyrite (e.g. Graham and Ohmoto, 1994) from the sericitising fluid (Fig. 9), possibly triggered by breakdown of anhydrite to release $\mathrm{SO}_{2}$ (Hutchinson and Dilles (2019); Hutchinson et al., 2020). This process produces significant acid, which would be able to hydrolyse feldspars, producing sericitic alteration. Sericitic alteration has been shown at other deposits to leach chalcopyrite (Brimhall, 1979). Pyrite can be precipitated in a Cu-enriched environment, and if more $\mathrm{Cu}$ is available than can be incorporated into the pyrite structure by solid solution, it precipitates as microparticles and is engulfed by the growing pyrite (Reich et al., 2013). This could explain the small inclusions of chalcopyrite within pyrite crystals in the Py > Ccp and Ccp-Py zones (Fig. 3f). 


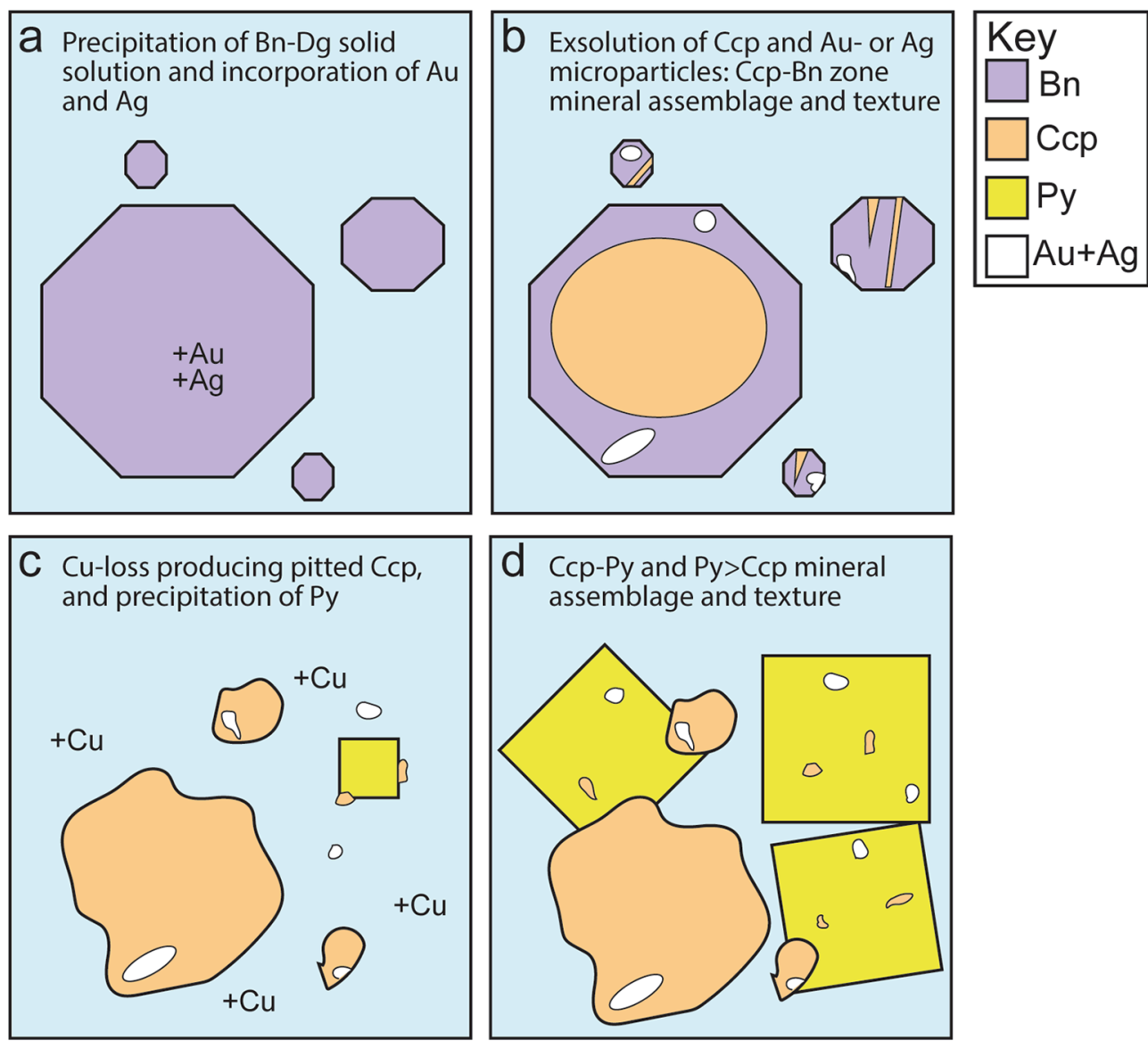

Fig. 9. Schematic model of formation of the mineralization zones in the Ann Mason deposit. a) precipitation of bornite-digenite solid solution from hydrothermal fluid, incorporating chalcophile precious metals into its crystal structure; b) exsolution of chalcopyrite and Ag- and Au-bearing microparticles through interaction with the fluid as bornite-digenite solid solution is recrystallized to bornite; c) partial dissolution of $\mathrm{Cu}$ sulphides and conversion of bornite to chalcopyrite during Cu-loss, and simultaneous precipitation of euhedral pyrite and microparticles of chalcopyrite and precious metal minerals from the hydrothermal fluid; d) growth of pyrite, incorporating microparticles into pyrite. Abbreviations: Bn bornite, Ccp chalcopyrite, Py Pyrite $\mathrm{Au}+\mathrm{Ag}$ microparticles.

\subsection{Precious and critical metal mineralisation at Ann-Mason and comparison with other porphyry deposits}

This study shows that the precious and critical metals in the AnnMason deposit are mostly present as microparticles $(<1-10 \mu \mathrm{m})$ of electrum or Au-Ag telluride and selenide minerals, hosted by bornite in the Ccp-Bn mineralisation zone.

Gold and silver are the most commonly analysed trace elements of interest in the literature on copper porphyry deposits. Gold is most commonly observed as $5-100 \mu \mathrm{m}$ particles of native, or high-fineness gold ( $<10 \% \mathrm{Ag}$ content) hosted within or at the edge of copper sulphides such as bornite and chalcopyrite (e.g. Batu Hijau, Red Chris, Kingking, Pebble, Bingham, Grasberg; Arif and Baker, 2004; Gregory et al., 2013; Rees et al., 2015; Rubin and Kyle, 1997; Suerte et al., 2007). More rarely, gold is hosted in pyrite (e.g. Assarel deposit; Cioacă et al., 2020) or by silicate minerals as 'free gold'. In some deposits, including the Red Chris, Granisle and Bell deposits, Au and Ag are predominantly present as electrum ( $>10 \% \mathrm{Ag}$ ), mostly hosted on the edge of bornite crystals (Cuddy and Kesler, 1982; Rees et al., 2015). Deposits such as Batu Hijau also contain invisible gold and silver held within the crystal structure of bornite, chalcopyrite or pyrite (Arif and Baker, 2004). Other minor forms of gold, silver and bismuth, such as tellurides and selenides, are reported at deposits such as Assarel, Rio Blanco, Santo Tomas II and Bingham (Ballantyne et al., 1998; Cioacă et al., 2020; Crespo et al., 2018; Tarkian and Koopmann, 1995). Deposits such as Santo Tomas II show relatively high concentrations of PGE, primarily held as PGM including merenskyite, kotulskite and moncheite (Tarkian and Koopmann, 1995).

At Ann-Mason, silver is present as invisible silver in bornite and to a lesser extent chalcopyrite and pyrite (J. Dilles, pers. comm.). Gold and silver microparticles in the Ccp-Bn zone mostly comprise tellurides and electrum, with subordinate Ag-selenides. The most prevalent by far is hessite (58\% of all microparticles in the Ccp-Bn zone). The majority of microparticles in the Ccp-Bn zone are hosted by bornite, which explains the close geochemical link between $\mathrm{Cu}$ and Ag (Fig. 4). In the Ccp-Py zone gold and silver microparticles mostly comprise selenides, especially naumannite $\left(\mathrm{Ag}_{2} \mathrm{Se}\right)$ and kurilite $\left(\mathrm{Ag}_{8} \mathrm{Te}_{3} \mathrm{Se}\right)$. Naumannite may be $\mathrm{Pb}$-bearing, but this is more common in the Ccp-Bn zone. The majority of microparticles in the Ccp-Py zone are hosted by chalcopyrite, with some hosted by pyrite, and a few isolated within silicates. The majority of microparticles hosted by chalcopyrite are found on the edge of the chalcopyrite. Microparticles containing $\mathrm{Bi}$ and $\mathrm{Hg}$ are more common in the Py > Ccp zone, as well as native gold. The majority of microparticles in the Py $>$ Ccp zone are hosted by pyrite, with a few hosted by chalcopyrite, but none is hosted within silicates.

\subsection{Formation of precious and critical metal microparticles}

There are several possible mechanisms to explain the deportment of precious and critical metals throughout the Ann-Mason deposit, including exsolution and precipitation directly from a fluid.

The distribution of metals between sulphides in the Ccp-Bn zone can most simply be explained by exsolution. Based on a compilation of data from various porphyry deposits by Kesler et al., (2002), Au is most abundantly found in solid solution in bornite, although it may also be present in chalcopyrite up to a few ppm (commonly ppb; George et al., 2018). In our samples the majority of electrum (Ag-Au) and hessite $\left(\mathrm{Ag}_{2} \mathrm{Te}\right)$ are observed in bornite.

Bornite precipitated directly from hydrothermal fluids, and partitioned other chalcophile elements ( $\mathrm{Au}, \mathrm{Ag}, \mathrm{Se}, \mathrm{Te}$ ) from the fluids into its crystal structure as it grew (Kesler et al., 2002; Simon et al., 2000). Silicate mineral assemblages associated with the sulphides (biotite $+\mathrm{K}$ - 
feldspar) suggest that the Cu-bearing assemblages formed at temperatures $>400{ }^{\circ} \mathrm{C}$ (Beane, 1974). Experimental and observational studies indicate that at $>350{ }^{\circ} \mathrm{C}$, bornite can contain $10 \mathrm{~s}$ to $100 \mathrm{~s}$ ppm of $\mathrm{Au}$ (Simon et al., 2000), >649 ppm of Ag (Reich et al., 2013), >10 wt $\%$ of Bi (at $300{ }^{\circ} \mathrm{C}$; Sugaki et al., 1984), $>2000 \mathrm{ppm}$ of Se and $>400 \mathrm{ppm}$ of Te (Cook et al., 2011). The concentration of each element that can be held in solution is temperature-dependent: for example, Au decreases from 1280 to $8200 \mathrm{ppm}$ at $600{ }^{\circ} \mathrm{C}$ to $235-364 \mathrm{ppm}$ at $500^{\circ} \mathrm{C}$ to $13-80 \mathrm{ppm}$ at $400{ }^{\circ} \mathrm{C}$ (Simon et al., 2000). During cooling, bornite undergoes recrystallisation to a crystal structure that is more stable at cooler temperatures (Li et al., 2018; Zhao et al., 2017), but that is able to host lower concentrations of trace elements in solid solution (Simon et al., 2000), causing precious metals to exolve as discrete minerals. Cook et al. (2011) found that both Se and Te are not especially compatible in bornite, and tend to exsolve as discrete microparticles. The process of exsolution may be facilitated and accelerated by interaction with fluids in the nanopores within bornite (Zhao et al., 2017).

The prevalence in the Ccp-Bn zone of hessite and electrum associated with bornite is consistent with exsolution of these minerals from solid solution (Fig. 9b). The majority of these hessite and electrum microparticles are located either at the edge of bornite, or along fractures or apparent porosity within bornite. The ratio of $\mathrm{Ag} / \mathrm{Cu}$ in the $\mathrm{Ccp}-\mathrm{Bn}$ zone is also more than three times that in the Ccp-Py or Py > Ccp zones (Table 1), suggesting that the majority of $\mathrm{Ag}$ is hosted by bornite.

This distribution is explicable through fluid-driven exsolution, but could also be caused by precipitation directly from a fluid. Alternatively, exsolution of the microparticles may have caused fracturing in the host sulphide, similar to that observed by the replacement of pyrite by chalcopyrite (Zhang et al., 2020).

Chalcopyrite is able to host a wide variety of trace elements, though typically in low concentrations unless not associated with another $\mathrm{Cu}$ - or Cu-Fe-sulphide (George et al., 2018). For example, when chalcopyrite coexists with bornite, the bornite will contain significantly higher $\mathrm{Ag}$ and Bi contents than the chalcopyrite (Cook et al., 2016, 2011). George et al., (2018) suggest that Ag likely substitutes for $\mathrm{Cu}$, while Se and $\mathrm{Te}$ are hosted in the $\mathrm{S}$ site. Observational studies show that chalcopyrite may contain up to $849 \mathrm{ppm} \mathrm{Se}$, up to $1.9 \mathrm{ppm} \mathrm{Te},>1000 \mathrm{ppm} \mathrm{Ag}$ and $0.24 \mathrm{ppm} \mathrm{Au}, 30 \mathrm{ppm}$ Bi in solid solution (George et al., 2018). These concentrations are likely temperature-dependent: experimental data show that the concentration of $\mathrm{Au}$ in solid solution decreases with temperature from 100 to $125 \mathrm{ppm}$ at $600{ }^{\circ} \mathrm{C}$, to $5-80 \mathrm{ppm}$ at $500{ }^{\circ} \mathrm{C}$ to 2-4 ppm at $400{ }^{\circ} \mathrm{C}$ (Simon et al., 2000).

The reduced capacity of chalcopyrite in the presence of bornite to partition trace elements is reflected in our data, with only $5-6 \%$ of hessite and electrum microparticles in the Ccp-Bn zone hosted by chalcopyrite. The majority of microparticles in the Ccp-Py zone are naumannite $\left(\mathrm{Ag}_{2} \mathrm{Se}\right)$ hosted by chalcopyrite, which is consistent with chalcopyrite containing an order of magnitude more Se than Te in solid solution (George et al., 2018; Reich et al., 2020). Se is also susceptible to fluid-rock interaction (Cook et al., 2011), so naumannite in the Ccp-Py zone may contain Se that has been remobilised and redeposited by fluids.

Experimental studies suggest that As-poor pyrite may contain 240 ppm and $300 \mathrm{ppm} \mathrm{Au}$ and Ag respectively, contained as chemicallybound invisible gold (Pokrovski et al., 2019) or as micro inclusions (Pal'yanova et al., 2015), which is significantly more than may be incorporated into chalcopyrite. However, in the Ccp-Py zone $72 \%$ of Agand Au-bearing particles are hosted by chalcopyrite and only $19 \%$ by pyrite, while most microparticles in the Py > Ccp zone comprise Bi- or $\mathrm{Hg}$-bearing minerals hosted by pyrite. The paucity of Au and Ag-bearing particles in pyrite suggests that the pyrite may have formed from a fluid relatively depleted in Au and Ag. Deditius et al. (2011) suggested that nanoparticles in pyrite may form either by exsolution or by direct precipitation from a fluid. The occurrence of high fineness native gold and of Bi-tellurides only in pyrite or isolated in silicates suggests that direct precipitation from a fluid is the more likely mechanism for these minerals.

Studies have shown that gold and silver minerals may precipitate even if the component elements are not saturated within the fluid (Gammons and Williams-Jones, 1997, 1995; Gregory et al., 2013; Kesler et al., 2002; Pokrovski et al., 2008; Simon et al., 2000; Williams-Jones and Heinrich, 2005), and these hydrothermal fluids could have directly precipitated nanoparticles of Au- and Ag-bearing minerals in pyrite nanopores during pyrite formation. Nanoparticles form from fluids when nucleation rates are much faster than growth rates (Hochella et al., 2008; Zhou et al., 2021). The nanoparticles could have coarsened through Ostwald ripening (Deditius et al., 2011; Ruiz-Agudo et al., 2014), and become trapped in the pyrite as the nanopores annealed. This interpretation is supported by the two-dimensional areal proportions of one of the native gold microparticles $\left(60 \mu \mathrm{m}^{2}\right)$ and its host pyrite $\left(49,390 \mu \mathrm{m}^{2}\right)$, giving a $2 \mathrm{D}$ proportion of $1,215 \mathrm{ppm} \mathrm{Au}$ in the pyrite, which is too much Au to have been originally chemically bound within the pyrite crystal.

\section{Conclusions}

This study shows that the precious and critical metals in the AnnMason deposit are mostly present as microparticles $(<1-10 \mu \mathrm{m})$ of electrum or Au-Ag telluride and selenide minerals, hosted by bornite in the Ccp-Bn mineralisation zone. Applications of these findings for industry include informing the degree of milling $(<10 \mathrm{um})$ required for precious metal liberation and mitigating the effects of the minor contaminants As and $\mathrm{Hg}$ that are present in the ores.

To summarise the formation of this deposit: bornite-digenite solid solution in the Ccp-Bn zone initially precipitated from the hydromagmatic fluids released from the porphyry dykes, incorporating some $\mathrm{Au}$ and Ag (Fig. 9). During cooling, the bornite-digenite solid solution recrystallised to bornite, causing the fluid-mediated exsolution of gold and silver microparticles. Some of the bornite also exsolved chalcopyrite lamellae and rims.

In the Ccp-Py and the Py > Ccp zones, low salinity, lower temperature fluids (Dilles and Einaudi, 1992) caused the precipitation of pyrite with chalcopyrite inclusions (Fig. 9). Pyrite formation produced significant acid, hydrolysing the feldspars to sericite, and triggered deposition of sparse microparticles of minerals including high-fineness gold, electrum, hessite and $\mathrm{Hg}$ - and Bi-tellurides, which were incorporated into the growing pyrite.

\section{Author contributions}

CKP, NDW, JM, TC, JC, JB and ZM analysed the samples as their undergraduate research projects. HMA collected the samples, compiled the students' data, completed the analyses and wrote the paper.

\section{Funding}

This work was supported by a California State University, Chico Research, Scholarly and Creative Activity grant to HMA in 2016, as well as several departmental undergraduate research awards to CKP, NDW, JM and JB.

This research did not receive any specific grant from funding agencies in the public, commercial or not for profit sectors.

\section{Declaration of Competing Interest}

The authors declare that they have no known competing financial interests or personal relationships that could have appeared to influence the work reported in this paper.

\section{Acknowledgements}

The authors thank Hudbay Minerals Inc. for samples and for 
permission to publish. Thank you to John Dilles and Kenneth Gibson for sharing their unpublished analytical data on $\mathrm{Au}$ and $\mathrm{Ag}$ contents of hydrothermal sulphides at Yerington, that were supported by NSF grant EAR-9018639 to JD. Many thanks also to John Dilles and an anonymous reviewer whose comments greatly clarified the manuscript. We also thank UC Davis for access to the EPMA. The authors would like to note that our samples were collected on the traditional lands of the Washoe and Northern Paiute people, and were analysed on the traditional lands of the Mechoopda and Konkow people. We recognise and respect their unique spiritual relationship with this land.

\section{Appendix A. Supplementary data}

Supplementary data to this article can be found online at https://doi. org/10.1016/j.oregeorev.2021.104339.

\section{References}

Agorhom, E.A., Skinner, W., Zanin, M., 2013. Influence of gold mineralogy on its flotation recovery in a porphyry copper-gold ore. Chem. Eng. Sci. 99, 127-138. https://doi.org/10.1016/j.ces.2013.05.037.

Amcoff, Ö., 1988. Experimental replacement of chalcopyrite by bornite: textural and chemical changes during a solid-state process. Mineralium Deposita 23 (4), 286-292.

Arif, J., Baker, T., 2004. Gold paragenesis and chemistry at Batu Hijau, Indoneisa: Implications for gold-rich porphyry copper deposits. Miner. Deposita 39 (5-6) 523-535. https://doi.org/10.1007/s00126-004-0433-0.

Ballantyne, G.H., Smith, T.W., Redmond, P.B., 1998. Distribution and Mineralogy of Gold and Silver in the Bingham Canyon Porphyry Copper Deposit, Utah. In: John, D. A., Ballantyne, G.H. (Eds.), Geology and Ore Deposits of the Oquirrh and Wasatch Mountains, Utah. Society of Economic Geologists, p. 0.

Banik, T.J., Coble, M.A., Miller, C.F., 2017. Porphyry Cu formation in the middle Jurassic Yerington batholith, Nevada, USA: Constraints from laser Raman, trace element, U $\mathrm{Pb}$ age, and oxygen isotope analyses of zircon. Geosphere 13 (4), 1113-1132.

Beane, R.E., 1974. Biotite stability in the porphyry copper environment. Econ. Geol. 69 (2), 241-256.

Brett, R., 1964. Experimental data from the system Cu-Fe-S and their bearing on exsolution textures in ores. Econ. Geol. 59 (7), 1241-1269.

Brimhall, G.H., 1979. Lithologic determination of mass transfer mechanisms of multiplestage porphyry copper mineralization at Butte, Montana; vein formation by hypogene leaching and enrichment of potassium-silicate protore. Econ. Geol. 74, 556-589. https://doi.org/10.2113/gsecongeo.74.3.556.

Carten, R.B., 1986. Sodium-calcium metasomatism; chemical, temporal, and spatial relationships at the Yerington, Nevada, porphyry copper deposit. Econ. Geol. 81, 1495-1519. https://doi.org/10.2113/gsecongeo.81.6.1495.

Cioacă, M.-E., Munteanu, M., Lynch, E.P., Arvanitidis, N., Bergqvist, M., Costin, G., Ivanov, D., Milu, V., Arvidsson, R., Iorga-Pavel, A., Högdahl, K., Stoilov, V., 2020. Mineralogical setting of precious metals at the assarel porphyry Copper-Gold Deposit, Bulgaria, as Supporting Information for the Development of New Drill Core 3D XCT-XRF Scanning Technology. Minerals 10, 946. https://doi.org/10.3390/ $\min 10110946$.

Cohen, J.F., 2011. Mineralogy and geochemistry of hydrothermal alteration at the AnnMason copper deposit, Nevada: Comparison of large-scale ore exploration techniques to mineral chemistry: M.Sc. thesis, Corvallis, Oregon, Oregon State University, 112 p. plus appendices.

Cook, N., Ciobanu, C., George, L., Zhu, Z.-Y., Wade, B., Ehrig, K., 2016. Trace element analysis of minerals in magmatic-hydrothermal ores by laser ablation inductivelycoupled plasma mass spectrometry: approaches and opportunities. Minerals 6, 111 . https://doi.org/10.3390/min6040111.

Cook, N.J., Ciobanu, C.L., Danyushevsky, L.V., Gilbert, S., 2011. Minor and trace elements in bornite and associated Cu-(Fe)-sulfides: a LA-ICP-MS study of bornite mineral chemistry. Geochim. Cosmochim. Acta 75, 6473-6496. https://doi.org/ 10.1016/j.gca.2011.08.021.

Crespo, J., Reich, M., Barra, F., Verdugo, J., Martínez, C., 2018. Critical metal particles in copper sulfides from the supergiant Río Blanco Porphyry Cu-Mo Deposit. Chile. Minerals 8, 519. https://doi.org/10.3390/min8110519.

Cuddy, A.S., Kesler, S., 1982. Gold in the Granisle and Bell copper porphyry copper deposits, British Columbia. In: Precious Metals in the Northern Cordillera. Association or Exploration Geochemists, Rexdale, Ontario, pp. 157-172.

Deditius, A.P., Utsunomiya, S., Reich, M., Kesler, S.E., Ewing, R.C., Hough, R., Walshe, J., 2011. Trace metal nanoparticles in pyrite. Ore Geol. Rev. 42 (1), 32-46. https://doi. org/10.1016/j.oregeorev.2011.03.003.

Dilles, J.H., 1987. Petrology of the Yerington Batholith, Nevada; evidence for evolution of porphyry copper ore fluids. Econ. Geol. 82, 1750-1789. https://doi.org/10.2113/ gsecongeo.82.7.1750.

Dilles, J.H., Einaudi, M.T., 1992. Wall-rock alteration and hydrothermal flow paths about the Ann-Mason porphyry copper deposit, Nevada; a 6-km vertical reconstruction. Econ. Geol. 87, 1963-2001. https://doi.org/10.2113/gsecongeo.87.8.1963.

Dilles, J.H., Einaudi, M.T., Proffett, J.M., Barton, M.D., 2000. Overview of the Yerington porphyry copper district: magmatic to nonmagmatic sources of hydrothermal fluids: Their flow paths and alteration effects on rocks and Cu-Mo-Fe-Au ores. Society of Economic Geologists Guidebook Series 32 (Part 1), 55-66.
Dilles, J.H., Solomon, G.C., Taylor, H.P., Einaudi, M.T., 1992. Oxygen and hydrogen isotope characteristics of hydrothermal alteration at the Ann-Mason porphyry copper deposit, Yerington, Nevada. Econ. Geol. 87, 44-63. https://doi.org/10.2113/ gsecongeo.87.1.44.

Dilles, J.H., Wright, J.E., 1988. The chronology of early Mesozoic arc magmatism in the Yerington district of western Nevada and its regional implications. Geol. Soc. Am. Bull. 100 (5), 644-652.

Durazzo, A., Taylor, L.A., 1982. Experimental exsolution textures in the system bornitechalcopyrite: genetic implications concerning natural ores. Mineral. Deposita 17 (1), 79-97.

Gammons, C.H., Williams-Jones, A.E., 1997. Chemical mobility of gold in the porphyryepithermal environment. Econ. Geol. 92, 45-59. https://doi.org/10.2113/ gsecongeo.92.1.45

Gammons, C.H., Williams-Jones, A.E., 1995. Hydrothermal geochemistry of electrum; thermodynamic constraints. Econ. Geol. 90, 420-432. https://doi.org/10.2113/ gsecongeo.90.2.420.

George, L.L., Cook, N.J., Crowe, B.B.P., Ciobanu, C.L., 2018. Trace elements in hydrothermal chalcopyrite. Mineral. Mag. 82 (1), 59-88. https://doi.org/10.1180/ minmag.2017.081.021.

Goldfarb, R.J., 2014. Tellurium: The Bright Future of Solar Energy. US Department of the Interior, US Geological Survey.

Graham, U.M., Ohmoto, H., 1994. Experimental study of formation mechanisms of hydrothermal pyrite. Geochim. Cosmochim. Acta 58 (10), 2187-2202. https://doi. org/10.1016/0016-7037(94)90004-3.

Gregory, M.J., Lang, J.R., Gilbert, S., Hoal, K.O., 2013. Geometallurgy of the Pebble porphyry copper-gold-molybdenum deposit, Alaska: implications for gold distribution and paragenesis. Econ. Geol. 108 (3), 463-482. https://doi.org/ 10.2113/econgeo.108.3.463.

Halley, S., Dilles, J.H., Tosdal, R.M., 2015. Footprints: hydrothermal alteration and geochemical dispersion around porphyry copper deposits. Soc. Econ. Geol. Newsl. 100 (1), 12-17.

Harris, D.C., 1990. The Mineralogy of gold and its relevance to gold recoveries. Miner. Deposita 25 (S1), S3-S7. https://doi.org/10.1007/BF00205243.

Hochella, M.F., Lower, S.K., Maurice, P.A., Penn, R.L., Sahai, N., Sparks, D.L., Twining, B. S., 2008. Nanominerals, mineral nanoparticles, and earth systems. Science 319 (5870), 1631-1635. https://doi.org/10.1126/science:1141134.

Hutchinson, M.C., Dilles, J.H., 2019. Evidence for magmatic anhydrite in porphyry copper intrusions. Econ. Geol. 114 (1), 143-152. https://doi.org/10.5382/ econgeo.2019.4624.

Hutchinson, M.C., Brooker, R.A., Dilles, J.H., Blundy, J., 2020. The stability and composition of sulfate melts in arc magmas. Contrib Mineral Petrol 175 (10). https://doi.org/10.1007/s00410-020-01729-6.

Johnson, K.M., Hammarstrom, J.M., Zientek, M.L., Dicken, C.L., 2014. Estimate of undiscovered copper resources of the world. US Geol. Surv. Fact Sheet 3004.

Kesler, S.E., Chryssoulis, S.L., Simon, G., 2002. Gold in porphyry copper deposits: Its abundance and fate. Ore Geol. Rev. 21 (1-2), 103-124. https://doi.org/10.1016/ S0169-1368(02)00084-7.

Li, K., Brugger, JoëL, Pring, A., 2018. Exsolution of chalcopyrite from bornite-digenite solid solution: an example of a fluid-driven back-replacement reaction. Miner. Deposita 53 (7), 903-908. https://doi.org/10.1007/s00126-018-0820-6.

Li, K., Pring, A., Etschmann, B., Xia, F., Brugger, J., 2020. Coupling between mineral replacement reactions and co-precipitation of trace elements: an example from the giant Olympic Dam deposit. Ore Geol. Rev. 117, 103267. https://doi.org/10.1016/j. oregeorev.2019.103267.

Pal'yanova, G., Mikhlin, Y., Kokh, K., Karmanov, N., Seryotkin, Y., 2015. Experimental constraints on gold and silver solubility in iron sulfides. J. Alloys Compd. 649, 67-75. https://doi.org/10.1016/j.jallcom.2015.07.131.

Palyanova, G.A., 2020. Gold and Silver Minerals in Sulfide Ore. Geol. Ore Deposits 62 (5), 383-406. https://doi.org/10.1134/S1075701520050050.

Pokrovski, G.S., Borisova, A.Y., Harrichoury, J.-C., 2008. The effect of sulfur on vapor-liquid fractionation of metals in hydrothermal systems. Earth Planet. Sci. Lett. 266 (3-4), 345-362. https://doi.org/10.1016/j.epsl.2007.11.023.

Pokrovski, G.S., Kokh, M.A., Proux, O., Hazemann, J.-L., Bazarkina, E.F., Testemale, D., Escoda, C., Boiron, M.-C., Blanchard, M., Aigouy, T., Gouy, S., de Parseval, P., Thibaut, M., 2019. The nature and partitioning of invisible gold in the pyrite-fluid system. Ore Geol. Rev. 109, 545-563.

Proffett Jr., J.M., 1977. Cenozoic geology of the Yerington district, Nevada, and implications for the nature and origin of Basin and Range faulting. Geol. Soc. Am. Bull. 88 (2), 247-266.

Proffett, J.M. and Dilles, J.H., 1984. Geologic map of the Yerington district, Nevada.

Proffett, J.M., 2007. Report on the Geology and Genesis of the Yerington Porphyry Copper District, Nevada, A Four Dimensional Study. As supported by USGS Mineral Resource External Research Program Grant 06HQGR0171 (USGS Mineral Resource External Research Program Grant 06HQGR0171).

Proffett, J.M., 2009. High Cu grades in porphyry Cu deposits and their relationship to emplacement depth of magmatic sources. Geology 37 (8), 675-678.

Redmond, P.B., Einaudi, M.T., Inan, E.E., Landtwing, M.R., Heinrich, C.A., 2004. Copper deposition by fluid cooling in intrusion-centered systems: new insights from the Bingham porphyry ore deposit. Utah Geol. 32 (3), 217-220.

Rees, C., Riedell, K.B., Proffett, J.M., Macpherson, J., Robertson, S., 2015. The Red Chris porphyry copper-gold deposit, northern British Columbia, Canada: igneous phases, alteration, and controls of mineralization. Econ. Geol. 110 (4), 857-888. https://doi. org/10.2113/econgeo.110.4.857.

Reich, M., Palacios, C., Barra, F., Chryssoulis, S., 2013. "Invisible" silver in chalcopyrite and bornite from the Mantos Blancos Cu deposit, northern Chile. Eur. J. Mineral. 25 (3), 453-460. https://doi.org/10.1127/0935-1221/2013/0025-2287. 
Reich, M., Román, N., Barra, F., Morata, D., 2020. Silver-Rich Chalcopyrite from the Active Cerro Pabellón Geothermal System, Northern Chile. Minerals 10, 113. https://doi.org/10.3390/min10020113.

Rubin, J.N., Kyle, J.R., 1997. Precious metal mineralogy in porphyry-, skarn-, and replacement-type ore deposits of the ertsberg (Gunung Bijih) district, Irian Jaya, Indonesia. Econ. Geol. 92, 535-550. https://doi.org/10.2113/gsecongeo.92.5.535.

Ruiz-Agudo, E., Putnis, C.V., Putnis, A., 2014. Coupled dissolution and precipitation at mineral-fluid interfaces. Chem. Geol. 383, 132-146. https://doi.org/10.1016/j. chemgeo.2014.06.007.

Rusk, B.G., Reed, M.H., Dilles, J.H., 2008. Fluid inclusion evidence for magmatichydrothermal fluid evolution in the porphyry copper-molybdenum deposit at Butte, Montana. Econ. Geol. 103 (2), 307-334.

Schouten, C., 1934. Structures and texture of synthetic replacements in" open space". Econ. Geol. 29 (7), 611-658.

Schulz, K.J., DeYoung, J.H., Seal, R.R., Bradley, D.C., 2018. Critical mineral resources of the United States: economic and environmental geology and prospects for future supply. Geol. Surv.

Sillitoe, R.H., 2010. Porphyry copper systems. Econ. Geol. 105 (1), 3-41.

Simon, G., Kesler, S.E., Essene, E.J., 2000. Gold in porphyry copper deposits: experimental determination of the distribution of Gold In the Cu-Fe-S system at $400^{\circ}$ to $700^{\circ}$ C. Econ. Geol. 95, 259-270.

Suerte, L.O., Nishihara, S., Imai, A., Watanabe, K., Yumul, G.P., Maglambayan, V.B., 2007. Occurrences of ore minerals and fluid inclusion study on the Kingking Porphyry copper-gold deposit, Eastern Mindanao, Philippines. Resour. Geol. 57 (2), 219-229. https://doi.org/10.1111/j.1751-3928.2007.00018.x.

Sugaki, A., Kitakaze, A., Hayashi, K., 1984. Hydrothermal synthesis and phase relations of the polymetallic sulphide system, especially on the Cu-Fe-Bi-S system. Mater. Sci. Earths Inter. 545-583.
Tarkian, M., Koopmann, G., 1995. Platinum-group minerals in the Santo Tomas II (Philex) porphyry copper-gold deposit, Luzon Island, Philippines. Miner. Deposita 30, 39-47.

Tungpalan, K., Wightman, E., Manlapig, E., 2015. Relating mineralogical and textural characteristics to flotation behaviour. Miner. Eng. 82, 136-140. https://doi.org/ 10.1016/j.mineng.2015.02.005.

Williams-Jones, A.E., Heinrich, C.A., 2005. 100th Anniversary Special Paper: Vapor Transport of Metals and the Formation of Magmatic-Hydrothermal Ore Deposits. Econ. Geol. 100 (7), 1287-1312. https://doi.org/10.2113/gsecongeo.100.7.1287.

Wilson, J.W.J., Kesler, S.E., Cloke, P.L., Kelly, W.C., 1980. Fluid inclusion geochemistry of the Granisle and Bell porphyry copper deposits, British Columbia. Econ. Geol. 75 (1), 45-61.

Zhang, Y., Cai, Y., Qu, Y., Wang, Q., Gu, L., Li, G., 2020. Two-stage fluid pathways generated by volume expansion reactions: insights from the replacement of pyrite by chalcopyrite. Sci. Rep. 10, 19993. https://doi.org/10.1038/s41598-020-76813-9.

Zhao, J., Brugger, J., Grguric, B.A., Ngothai, Y., Pring, A., 2017. Fluid-enhanced coarsening of mineral microstructures in hydrothermally synthesized bornitedigenite solid solution. ACS Earth Space Chem. 1 (8), 465-474. https://doi.org/ 10.1021/acsearthspacechem.7b00034.

Zhao, J., Brugger, J., Ngothai, Y., Pring, A., 2014. The replacement of chalcopyrite by bornite under hydrothermal conditions. Am. Mineral. 99 (11-12), 2389-2397. https://doi.org/10.2138/am-2014-4825.

Zhou, H., Wirth, R., Gleeson, S.A., Schreiber, A., Mayanna, S., 2021. Three-dimensional and microstructural fingerprinting of gold nanoparticles at fluid-mineral interfaces. Am. Mineral. 106, 97-104. https://doi.org/10.2138/am-2021-7696. 